\title{
Vilanova Artigas: a poética traduzida
}

\section{Vilanova Artigas: the translated poetics}

\section{Marcos Faccioli Gabriel}


Resumo: Abordamos aqui a obra do influente e controvertido arquiteto Vilanova Artigas, ativo em São Paulo entre as décadas de 1940 e 1970, como obra de arte autônoma, pois esta mostra um uso figurativo de estruturas trilíticas de concreto armado, o qual operava uma fusão da linearidade dos membros com a criação volumétrica no mesmo material. Seus projetos mostravam, por um lado, uma disposição volumétrica e estrutural serial ao longo de um eixo e, por outro, a alternância no percurso do observador entre massa cerrada e espaço, entre luzes intensas e sombras profundas, entre peso e resistência, contrastes estes que a tradição atribui ao sublime arquitetônico, à visão do drama humano do trabalho que, afinal, ergue as estruturas além da medida razoável da utilidade. Exceder esta medida põe a obra em conflito com o marxismo do militante Artigas, mas também a põe no terreno da arquitetura moderna enquanto "estilo da modernidade”, em conflito, segundo Reyner Banham (1970, p.327), com o desenvolvimento ininterrupto da técnica com a qual pretendia legitimar-se.

Palavras-chave: Vilanova Artigas; Teoria da arquitetura; Estética arquitetônica; Crítica de arquitetura; Crítica de arte.

Abstract: We hereby broach the architectural oeuvre by influential and controversial architect Vilanova Artigas, active in São Paulo between the 1940s and the 70s. We take the stand of treating this modern architectural work as an autonomous artwork that puts up a figuration out of reinforced concrete beam and lintel structures, which worked out a fusion between linear members and volumetric configuration in the same material, reinforced concrete. His designs exhibit on the one hand a serial disposition of both volumes and structure alongside an axis, and on another they alternate alongside the viewer's path between mass and space, between intense lights and deep shadows, between weight and resistance, contrasts which tradition assigns to the sublime, to the tragic view of human toil that raises structures far beyond the measure of sound utility. This 
excess sets his work at odds with his own Marxist creed about the exploitation of work but it is grounded on the project of modern architecture as style of modern times which would nonetheless be in stark opposition, according to Reyner Banham (1970, p. 327 ), to the uninterrupted development of technology through which it aimed at legitimizing itself.

Keywords: Vilanova Artigas; Architectural theory; Architectural aesthetics; Architectural criticism; Art criticism. 


\section{Estranho}

Graduado engenheiro arquiteto em 1937 pela Escola Politécnica da Universidade de São Paulo (USP) e membro do Partido Comunista Brasileiro (PCB) desde 1943, Artigas combinou como ninguém a atividade profissional com a militância política. No PCB, foi dirigente em meados dos anos 1950, quando aquele partido optou por dar apoio e, subsequentemente, participar no Governo Juscelino Kubitschek e na consecução de sua meta máxima: a construção de Brasília. A obra de Artigas amadureceu nesses mesmos anos e eclodiu já nos anos finais da construção da nova capital federal e nos inícios da década de 1960; sendo uma pesquisa arquitetônica pessoal, nem por isso deixou de buscar criar um modelo que a arquitetura brasileira pudesse seguir, modelo de excelência técnica e estética a ser imitado. Não admira que o termo "arquitetura paulista” sugira ainda o velho ideal de um estilo da modernidade, ainda que na feição de uma versão local ou nacional, nos limites dos recursos técnicos e do clima. Artigas deixou clara a frustração de em vida não ter visto a natureza artística de sua obra reconhecida e criticamente elaborada; com efeito, somente após a sua morte é que surgiram trabalhos dessa natureza.

Para que as coisas se dessem desse modo, alguns fatos podem ser arrolados. Nos anos de 1950, Mário Pedrosa (1981d, 1981e) foi a grande voz pública por uma arquitetura arte que, por sê-lo, seria socialmente transformadora, através de Brasília e da ruptura do padrão dualista litoral e sertão. Em 1961, quando ficou claro que Brasília se deixava colonizar pela política tradicional brasileira, Pedrosa já manifestava ceticismo para com a arquitetura arte no Congresso Nacional de Críticos de Arte de 1961.

Durante as décadas de 1960 e 70, a arquitetura foi se afastando do ambiente artístico das vanguardas construtivas e foi se aproximando da arquitetura ciência, com enorme proliferação de disciplinas nos cursos universitários e de saberes especializados presentes na prática arquitetônica, com o consequente deslocamento da arquitetura arte e pelo que a ela subjazia, o estilo da modernidade. Pedrosa (2015b), em 1970, definitivamente renegaria a arquitetura arte como ideologia conservadora a ser desmascarada e saudava a arquitetura ciência como muito mais capaz de promover a satisfação das graves necessidades populares no Brasil. Artigas talvez tenha participado dos dois movimentos, tanto a tendência pela ciência, quanto certo desconsolo pelo afastamento da arte. Mas o que importa, sobretudo, é que essa conjunção de situações talvez explique porque o estudo artístico de sua obra tenha se dado 
tão tardia e postumamente.

Os três estudos que abordam a obra de Artigas como obra de arte de que temos notícia - Kamita (2000), Buzzar (2014) e o presente - são bastante diversos entre si e apresentam diferente ênfase nas relações entre arte e política, atividades definidoras do perfil e da personalidade de Artigas. A monografia de Masao Kamita (2000) tem uma abordagem fenomenológica da obra, mas termina por compreendê-la de modo demasiado solidário ao discurso político de seu autor. Já Miguel A. Buzzar (2014) empreende um amplo estudo, uma biografia intelectual, profissional e política de Artigas, porém a compreensão das obras ressente-se de uma homogeneidade muito marcada com o que julgava terem sido os traços de sua política. Metodologicamente este passo dá o que pensar: será que a autonomia dos meios artísticos não pode até mesmo dizer algo diverso do discurso político do artista?

O presente trabalho, que parte da dúvida que acabamos de apresentar, procura dar mais ampla autonomia às formas da obra de Artigas e ligar essa apreciação formal à literatura teórico-estética da arquitetura, a qual chegou até nosso ambiente, pelo menos através da proposição da síntese das artes por Pedrosa (GABRIEL, 2017). Tal proposição remonta à Gesamtkunstwerk oitocentista e, mais remotamente, ao projeto do estilo arquitetônico da modernidade que surgiu em 1828 com o livro "Em que estilo deveríamos construir?", de autoria do arquiteto Heinrich Hübsch (1992). Esta abertura de perspectivas que tampouco deixou de checar o discurso político do arquiteto, permitiu abrir o leque de significações em direção a autores tanto do passado, quanto da contemporaneidade.

À guisa de contexto ainda, para o sucesso do empreendimento “Brasília”, a arquitetura moderna brasileira contribuiu não apenas operacionalmente, mas com seu prestígio e com a credibilidade que conquistara para a juntura entre a modernidade e a composição étnica incerta do Brasil. Para o imaginário, nenhuma outra realização fora tão convincente nesta direção, ainda que os primeiros anos da década de 1950 tenham sido de crise em duas frentes. Por um lado, a arquitetura moderna brasileira era criticada pela opinião profissional internacional, em particular por Max Bill, como de um formalismo ou esteticismo ingênuo. Por outro, a sua finalidade imanente de integração social à modernização caía em descrédito com os rumos que a economia do país tomava. Desde 1953, o crítico de arte Mário Pedrosa tornou-se figura importante em restabelecer a ligação, então rompida, entre a arquitetura brasileira, o desenvolvimento e a tão desejada integração social. E eis que 
surgiu o projeto de construção da Nova Capital para que Pedrosa pudesse religar entusiasticamente as duas faces da arquitetura moderna brasileira, agora simbolizadas pelo "Plano Piloto" de Lúcio Costa e pela nova arquitetura que Niemeyer desenvolveu após 1953.

Pedrosa (1981b), ao promover a religação entre a arte arquitetônica e a satisfação de necessidades coletivas, precisava esclarecer o que estava pendente: a arquitetura brasileira como arte. Ao dar-se conta do fim da "terrível dieta funcional", Pedrosa juntava-se ao historiador da arquitetura Sigfried Giedion que desde 1943 saudava o retorno da arquitetura-obra de arte em íntima conexão com o dar forma a uma sociabilidade da proximidade, algo que o pensamento milenarista desses autores via surgir: Giedion com o fim da II Guerra Mundial e Pedrosa com a construção de Brasília (GIEDION; SERT; LÉGER, 1993). Para o crítico, Brasília tornava-se, assim, um experimento de alcance mundial e, desse modo, o apregoara no Congresso Internacional Extraordinário de Críticos de $\mathrm{Arte}^{2}$ que organizou em 1959, sob o tema da cidade obra de arte coletiva ou "A Cidade Nova, Síntese das Artes” (PEDROSA, 1981c).

\section{O partido típico de projeto}

Artigas nos anos de 1950, a despeito da produção reduzida no período em que foi dirigente do PCB, mostrou um admirável experimentalismo em obras modestas tais como a Casa Baeta (1956), a Casa José F. Fernandes (1957) (Fig. 1) e a Casa Rubem de Mendonça (1956) (Fig. 2), esta última conhecida como “Casa dos Triângulos”. A obra da maturidade profissional de Artigas, aquela que apresenta os traços definitivos de sua arquitetura, já se deu num período, após 1957 ou 1958, diverso daquele de Pampulha e do suposto esteticismo ingênuo de que Niemeyer fora acusado. Essa arquitetura já se dava sob o chamado de Pedrosa (1981a, 2015b) à renovação das finalidades da arquitetura moderna brasileira, como sendo o desenvolvimento com integração social ou a estética unida indissoluvelmente à integração social. Essa arquitetura aparecia em obras de 1958/59, como a Casa Orlando Martinelli (1958), que retomava o princípio de composição desenvolvido em obras do período 1944-53 para obras de engenharia intensiva, como no estudo para o Esporte Clube Pinheiros, no estudo para o estádio e o conjunto poliesportivo de Londrina e, de modo mais convincente e realizado, no Estádio do Morumbi (1952) (Fig. 3 e 4). Trata-se de gerar espaços pela repetição de um padrão estrutural ao longo de um eixo ou de uma circunferência, um padrão que simultaneamente resolvia a organização 
em corte e que fazia a articulação entre os níveis do terreno e os da construção. No Estádio do Morumbi, esse método gerava a expressão volumétrica, nas arquibancadas superiores em balanço e com o espaço interior numa relação de correspondência positivo e negativo com o volume.

Figura 1 - Vilanova Artigas. Casa José F. Fernandes (1957)

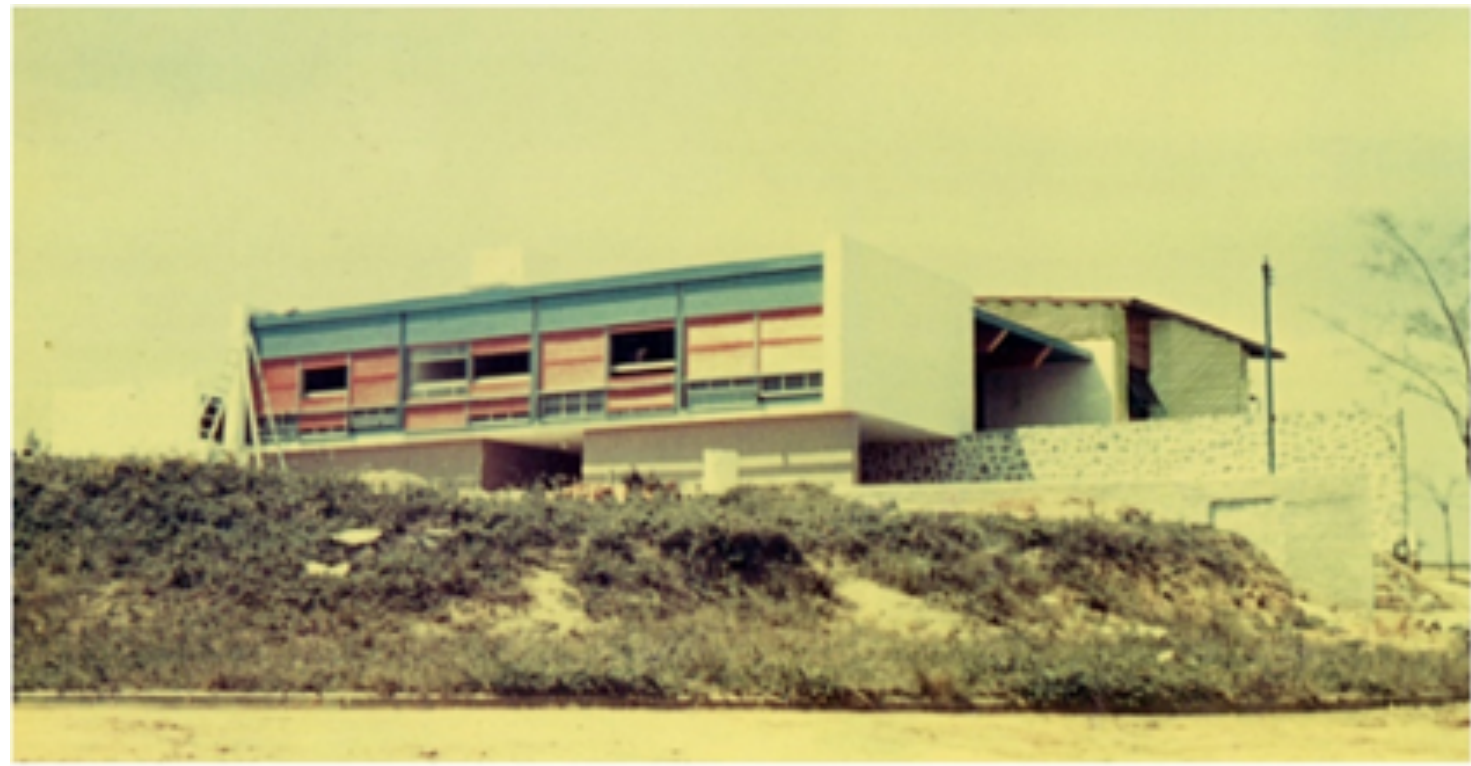

Fonte: Fundação Vilanova Artigas.

Figura 2 - Vilanova Artigas. Casa Rubem de Mendonça (1956)

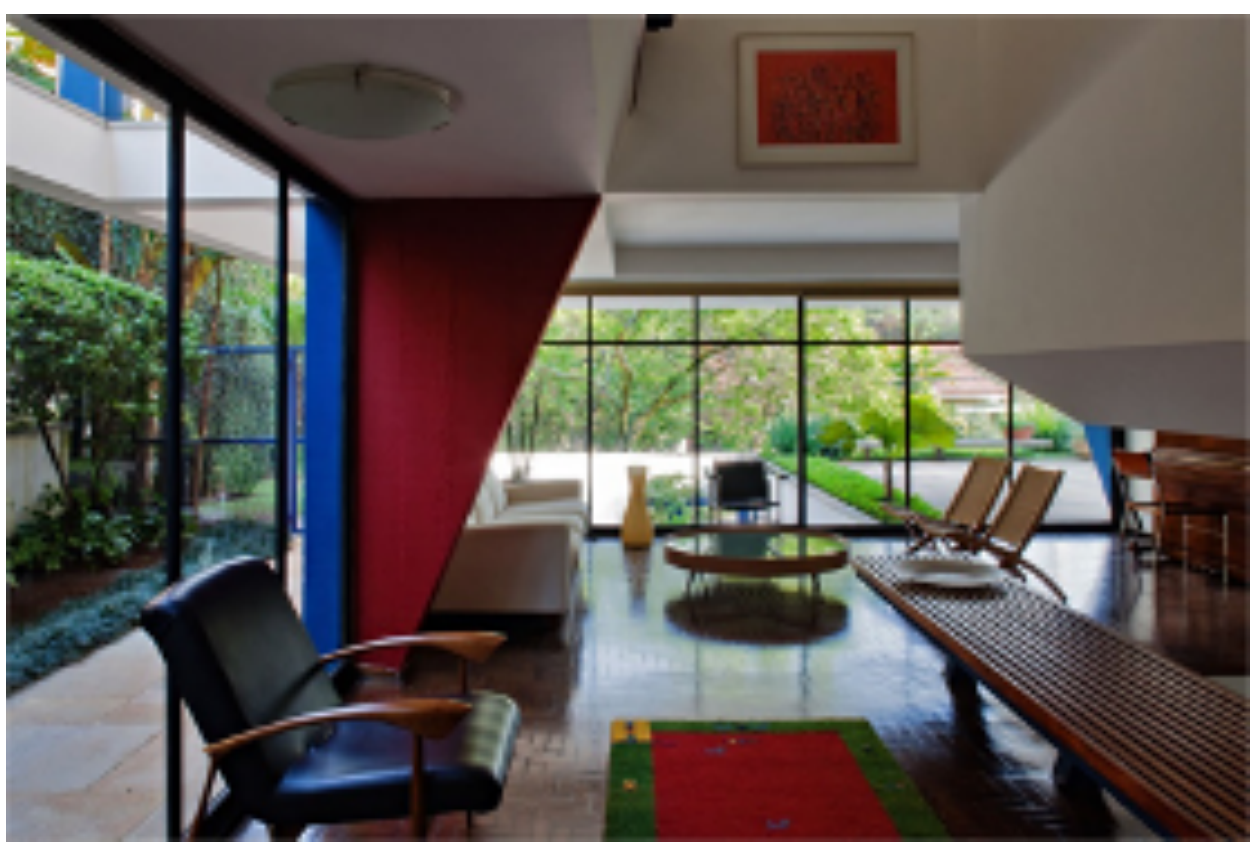

Fonte: fotógrafo Nelson Kon 
Figura 3 - Vilanova Artigas. Estádio do Morumbi em construção - arquibancadas em balanço (1952)

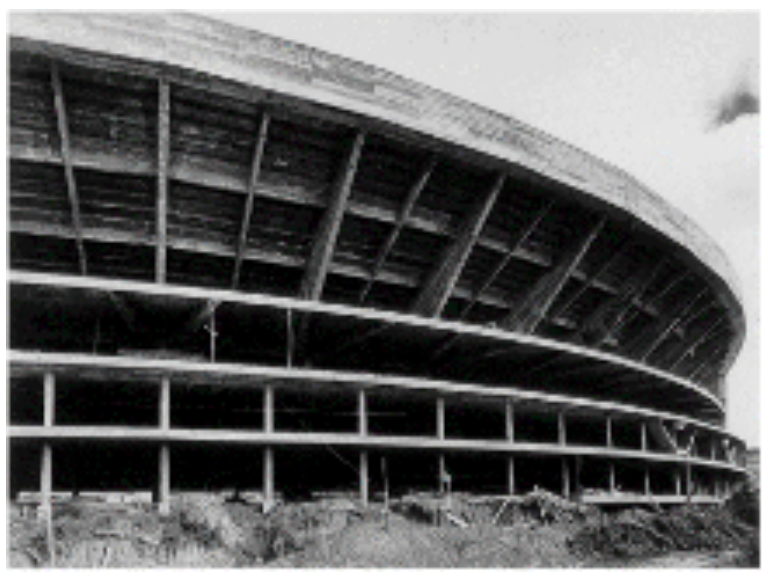

Fonte: Fundação Vilanova Artigas

Figura 4 - Vilanova Artigas. Estádio do Morumbi; seção transversal (1952)

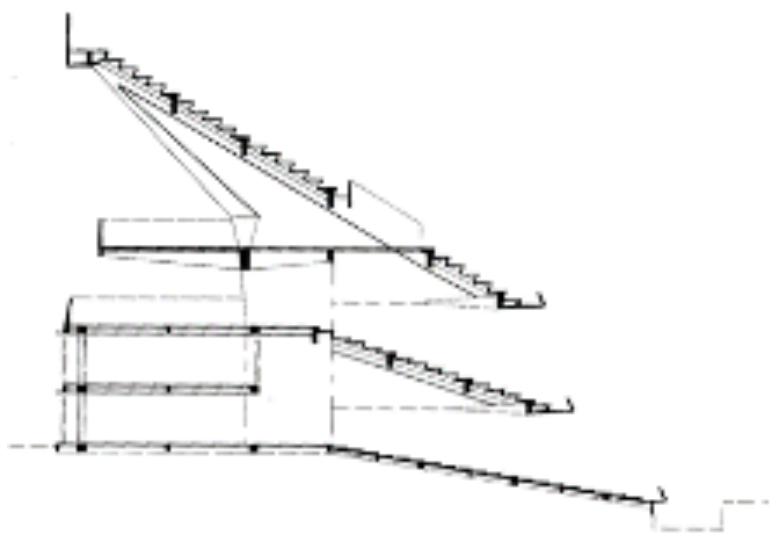

Fonte: Fundação Vilanova Artigas
Foi na Casa Baeta (1956) que Artigas introduziu as célebres “empenas” de concreto aparente. Mas foi na Casa José Mário Taques Bittencourt (1959) (Fig. 5), que o arquiteto aprimorou e deu forma acabada às empenas, ou seja, às paredes estruturais externas de concreto, como padrão estrutural, definição volumétrica e princípio figurativo. É quando Artigas passava a recortar as empenas de modo a figurar um volume massivo sobre apoios pontuais. O desenho destas empenas resultava do princípio estrutural que vai buscar os pontos de apoio no terreno e, assim, arma o jogo de distinção e interpenetração entre a configuração altimétrica do terreno e a volumetria compacta, minimalista por assim dizer.

Esta Casa, e várias outras do período, preserva todas as pesquisas de seu autor desde inícios da década de 1950, pesquisas sobre a implantação nos lotes paulistanos e as inversões hierárquicas pelas quais serviços e dependências de empregados são deslocados para o recuo de frente do lote e enclausurados por um material distinto, o muro de pedra. $\mathrm{O}$ fundo do lote e os recuos laterais tornam-se prolongamentos do interior onde transcorre a vida familiar, protegidos do mundo lá fora. 
Figura 5 - Vilanova Artigas. Casa José Mário Taques Bittencourt (1959)

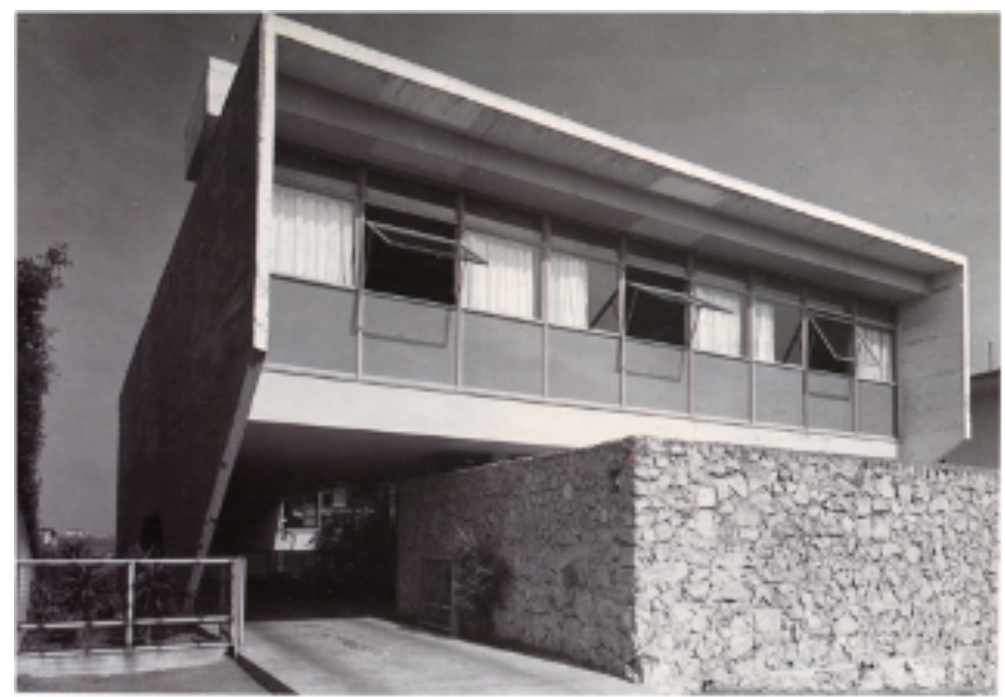

Fonte: Fundação Vilanova Artigas.

Esta "nova” arquitetura de Artigas constituiu um partido típico de projeto flexível o bastante para vencer uma ampla variedade de programas, se é que não qualquer programa. Esta flexibilidade que, poderia parecer um milagre, de fato advinha da constituição de um padrão estrutural que gerava espaços, segundo intervalos escolhidos em função das possibilidades do material estrutural, do programa, do terreno e de outros condicionantes, e que mantinha esse padrão independentemente dos espaços e partições utilitárias, graças à capacidade portante elevada desse padrão estrutural. Assim, escolas, clubes, laboratórios, estações de transportes ou colônias de férias de sindicatos cabiam, por assim dizer, no mesmo partido, sendo cada um destes como que um passo ou uma tentativa em busca de sua própria perfeição. Mas esse tipo de recorrência não é o que se vê em obras artísticas como nas pinturas de Mondrian ou nas de Morandi, por exemplo?

Formulado o partido típico de projeto, não há como deixar de dar-se conta de que fugia ao determinismo técnico-material, segundo o qual uma obra de arquitetura responde tão somente e exatamente ao programa de uso, às condições do sítio e às técnicas e materiais disponíveis. Acreditou-se à época que tal determinismo técnico-material fosse perseguido pela arquitetura moderna. Em todo caso, na modernidade as condições nos limites de uma situação geográfica, numa mesma sociedade e num certo nível de desenvolvimento, não dão origem a uma tipificação de soluções nem remotamente tão estrita quanto aquela presente nos projetos de Artigas. Porém, na medida da ambição e do talento do arquiteto, a reunião de elementos técnicos recorrentes pode 
encontrar-se com imagens artísticas cujo todo de sentido é a pesquisa estética do autor, sua poética, o que de modo nenhum podemos confundir com um estilo, como havia em épocas passadas da história.

Obviamente, formular a poética se baseia na possibilidade de conhecer uma obra arquitetônica tomando-a como se dá a uma intelecção diferenciada, a uma contemplação desinteressada; mas isto já levanta imediatamente a pergunta sobre qual, para os objetos técnicos da arquitetura, possa ser o sentido da imagem sensível. Algumas palavras de Artigas, desde que se ponha de lado a exigência de precisão terminológica, podem ser entendidas como uma declaração de intenções artísticas: “Do sofrimento do nosso povo, posso dizer que participei profundamente. Alguém terá olhos para, um dia, ler nas formas que projetei, todo esse sofrimento. Se verá uma poética traduzida” (ARTIGAS, 1997, p. 28)

\section{Repúdio à imitação da natureza: o grande vão e os sistemas trilíticos}

Nos edifícios de Artigas, como o da Faculdade de Arquitetura e Urbanismo da USP, FAUUSP, (1961) que veremos nas Figuras 15 a 19 adiante, a estrutura não era apenas suporte de elementos definidores da volumetria, lajes e paredes, fundiase com o próprio volume em prol de uma hipérbole estrutural. As empenas de concreto fundiam a função viga com as funções volume e espaço de modo que o aspecto externo da edificação fosse de uma grande viga e de seus apoios, as colunas periféricas. Ou então, como no Ginásio de Itanhaém (1959) (Fig. 6), a laje caixão-perdido da cobertura adquiria uma espessura volumétrica e, na articulação com os pilares ou lâminas portantes nas extremidades, formava a imagem de um pórtico que ao repetir-se modelava uma massa com espessura própria. Repare-se que a omissão de um pilar mediano nos pórticos extremos da série perfazia a imagem de um grande vão.

A garagem de barcos do Santa Paula Iate Clube (1961) (Fig. 7 e 8), era quase que apenas uma pesada cobertura, sob a qual os volumes utilitários, meio enterrados no solo, perfaziam como que um pedestal. Uma obra com aquele tipo de exigências funcionais poderia ter tido a cobertura resolvida, dados os recursos da época da construção, com cascas de concreto ou de alvenaria armada, com evidente economia. Em vez disso, Artigas, por assim dizer, optou por um massivo manifesto trilítico para o qual não havia qualquer determinante funcional ou construtivo, muito pelo contrário. Tratava-se de uma escolha artística de repertório. 
Figura 6 - Vilanova Artigas. Ginásio de Itanhaém (1959)

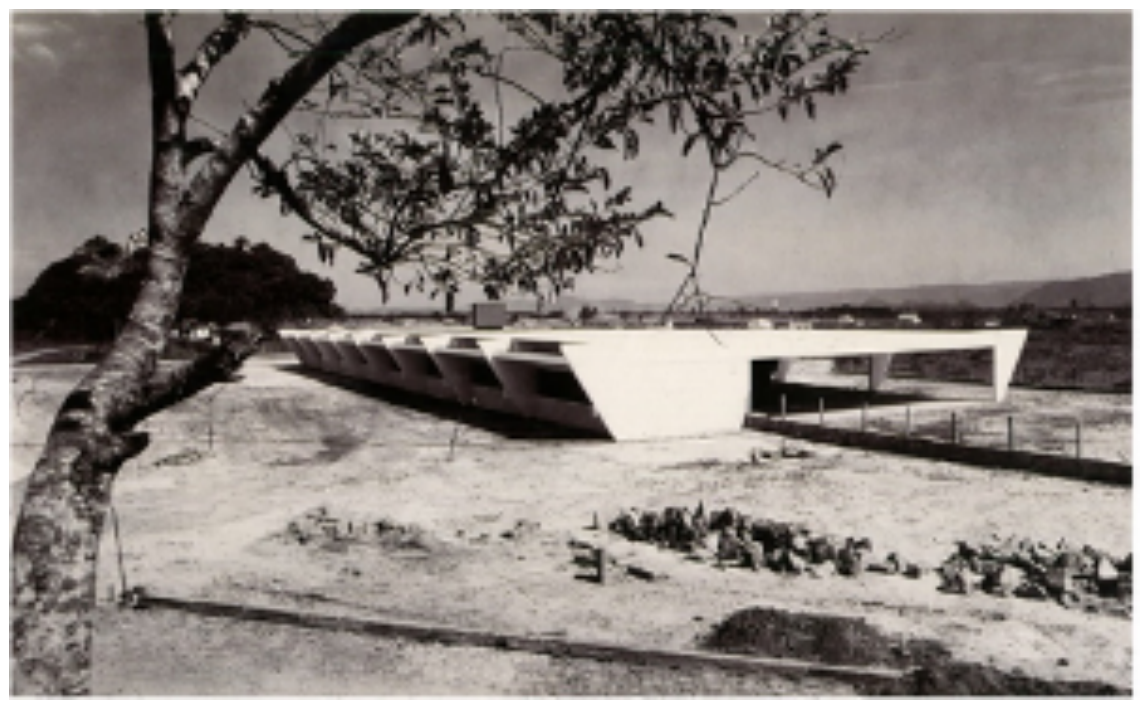

Fonte: Fundação Vilanova Artigas.

A julgar por algumas passagens de seus escritos não publicados, Artigas desprezava por profundos motivos as estruturas que imitassem a forma resistente de fenômenos naturais, porém, comentava com ironia o entusiasmo de Nervi por tais sistemas:

[...] sendo melhores entre os vários possíveis aqueles que mais se assemelham às estruturas naturais: cálices de flores, espigas de grãos, envolturas de insetos'. [...] referindo-se a algumas estruturas que realizou dentro do espírito acima, diz que as fez dentro de [...] considerações exclusivamente econômicas e técnicas [...] e só depois de tê-las realizado notei as possibilidades formais e arquitetônicas que suscitam'. [...] 'são observações importantes para a definição das relações entre técnica e arquitetura, e põe em relevo suas íntimas vinculações através de profundas e ocultas correspondências'. É a mística da harmonia (ARTIGAS, 1960/1975a, p. 9).

Em outra passagem de seus escritos nunca publicados ${ }^{3}$, Artigas endossava a surpreendente crítica de Candela ao funcionalismo, segundo a qual haveria um certo anacronismo na arquitetura moderna, pois um unívoco funcionalismo, perfeitamente lógico e impessoal a partir de premissas iniciais, corresponderia a uma crença na “infalibilidade e exatidão do raciocínio científico, já filosoficamente ultrapassada na época do surgimento da arquitetura moderna”: 
[...]. Sirva esta digressão para que se vá pensando em outra justificativa para a arquitetura atual, já que parece necessário justificá-la e explicá-la, e para que os estudantes deixem de perguntar indefectivelmente se uma certa forma está justificada pela função. Algo deve andar mal nas artes plásticas quando é preciso arranjar para elas justificações literárias e racionalistas. [...] (ARTIGAS, 1960/1975a, p. 15).

Figura 7 - Vilanova Artigas. Garagem de barcos do Sta. Paula Iate Clube; desenhos (1961)

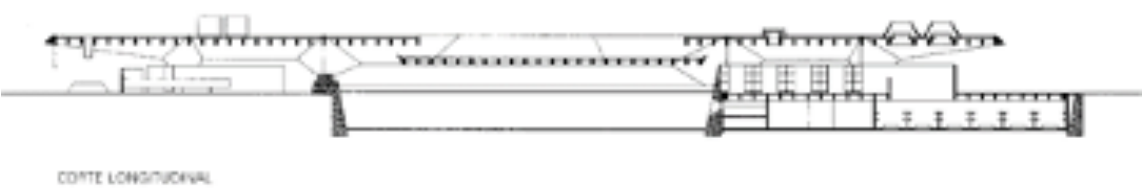

7

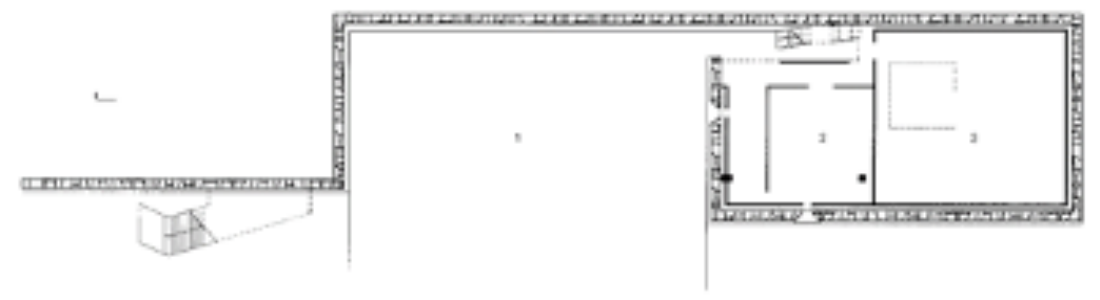

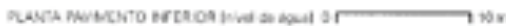
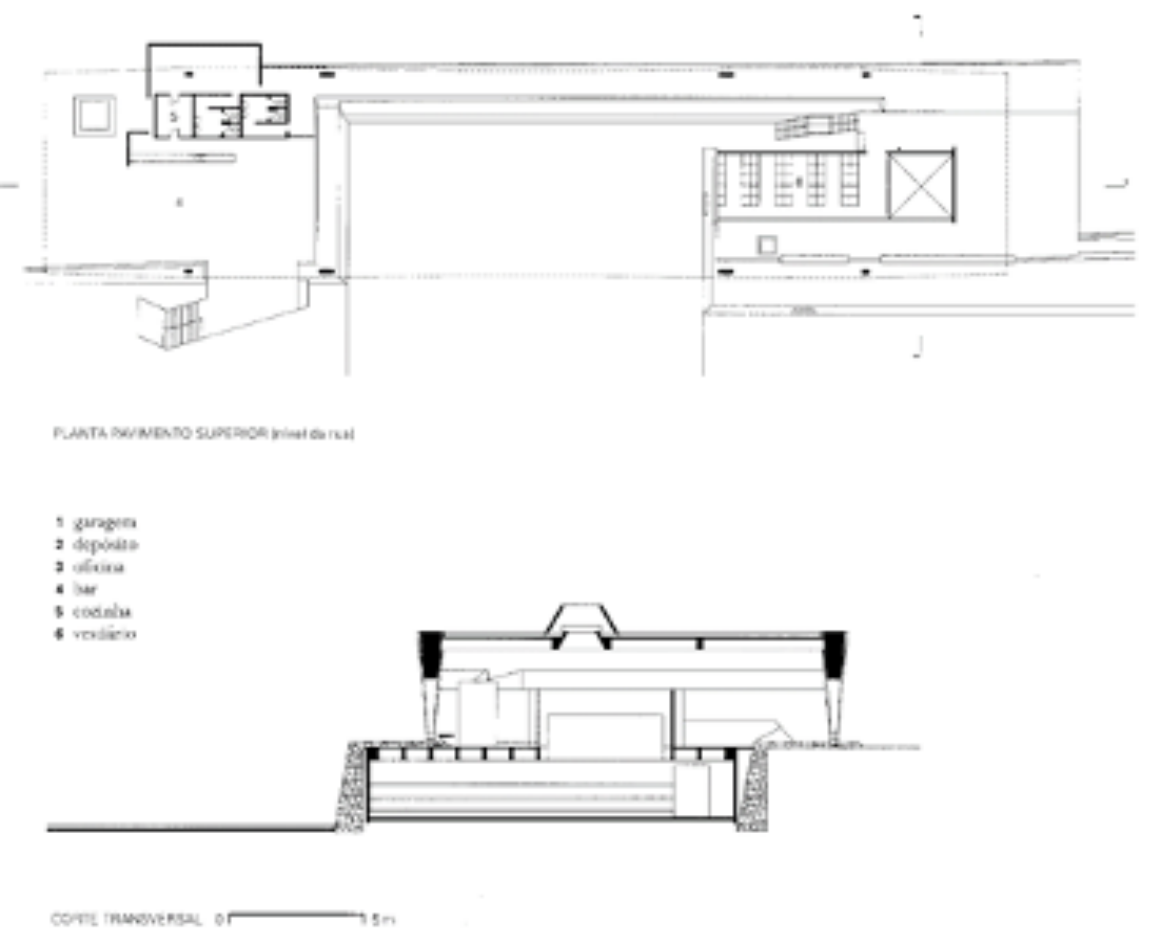

Fonte: Fundação Vilanova Artigas. 
Em suas notas, Artigas (1960/1975a) comparecia numa posição que mostrava variação de registro ou de referência que poderia causar espécie em leitores seus contemporâneos. O arquiteto punha, de um lado, "o homem e seus projetos" que não aceitariam limites à ambição estética e, de outro, os condicionantes, as considerações sociais e a autoridade da ciência que pronunciariam um “não pode”. Este "não pode”, Artigas o compreendia como uma voz de "classe conservadora" e de uma técnica tímida diante de suas próprias conquistas (ARTIGAS, 1960/1975b, p. 1). Mas esta sua negatividade anárquica não estaria na mais flagrante contradição com expressões suas muito mais conhecidas como a austera "moral construtiva”? Qual a razão de registros tão destoantes?

Nos projetos de sua maturidade profissional, a preferência absoluta por sistemas de vigas e colunas, os sistemas trilíticos, resultava, portanto, do repúdio a estruturas que "imitassem" as formas naturais, ou seja, em favor das estruturas “antinaturais”, por assim dizer. Desta forma, os apoios mínimos eram claramente mostrados (Fig. 8) e se tornavam um princípio figurativo, pois invertiam frontalmente a acomodação ao sentido da gravidade e da continuidade vertical dos apoios. A ampliação da extensão horizontal entre os pontos de apoio evidenciava, no concreto armado, o aço trabalhando a tração. Mais do que isso, expressava o conflito entre o peso e a resistência do modo mais claro, conduzindo as cargas às fundações pelo caminho mais longo e circundante, na horizontal, ou à distância mais longa que a tecnologia permitisse vencer entre os pontos de apoio. A fusão das vigas com a definição volumétrica do edifício, como nas empenas de concreto do prédio da FAUUSP, acentuava proporções no sentido da hipérbole de massa e peso e, de tal modo, dramatizavam a realização técnica de vencer o vão. Sobre a realização ambiciosa do artifício, Artigas (1989, p. 72) se expressava deste modo: “Não tenho nada a ver com a força da gravidade, é um obstáculo absurdo, que a ideia, o pensamento e a sensibilidade podem negar dialeticamente. E negam-no cantando”.

A compreensão da obra de Artigas pode beneficiar-se das observações de Arthur Schopenhauer (1969, v. 1, p.213-218) sobre as virtualidades estéticas da arquitetura. O filósofo do pessimismo assinalava à arquitetura uma posição hierárquica inferior entre as artes, cuja missão artística seria dar objetivação estética aos fenômenos inferiores da “vontade”, aqueles da natureza inanimada, por evidenciar o conflito entre as forças básicas do peso e da resistência, através da condução das cargas à terra pelo caminho mais longo possível, pela satisfação do pulso gravitacional por caminhos indiretos e circundantes. Consoante, no sistema estrutural grego, por exemplo, o peso que a massa do 
entablamento exerce deveria ser conduzido pela arquitrave até as altas colunas e por meio delas, somente, chegar à terra. O conflito assim prolongado daria visibilidade à ação incansável das forças cuja completa satisfação seria um monte de pedras ou de entulhos sobre o solo. Arthur Schopenhauer (1969, v. 2, p. 411-412) condenava, do ponto de vista exclusivo da arquitetura como arte, os sistemas de arcos e abóbodas, resistentes pela sua forma, porque tendiam a fundir em contínuos indistintos a massa suportada e os elementos de suporte.

Figura 8 - Vilanova Artigas. Garagem de barcos do Sta. Paula Iate Clube - ponto de apoio estrutural (1961)

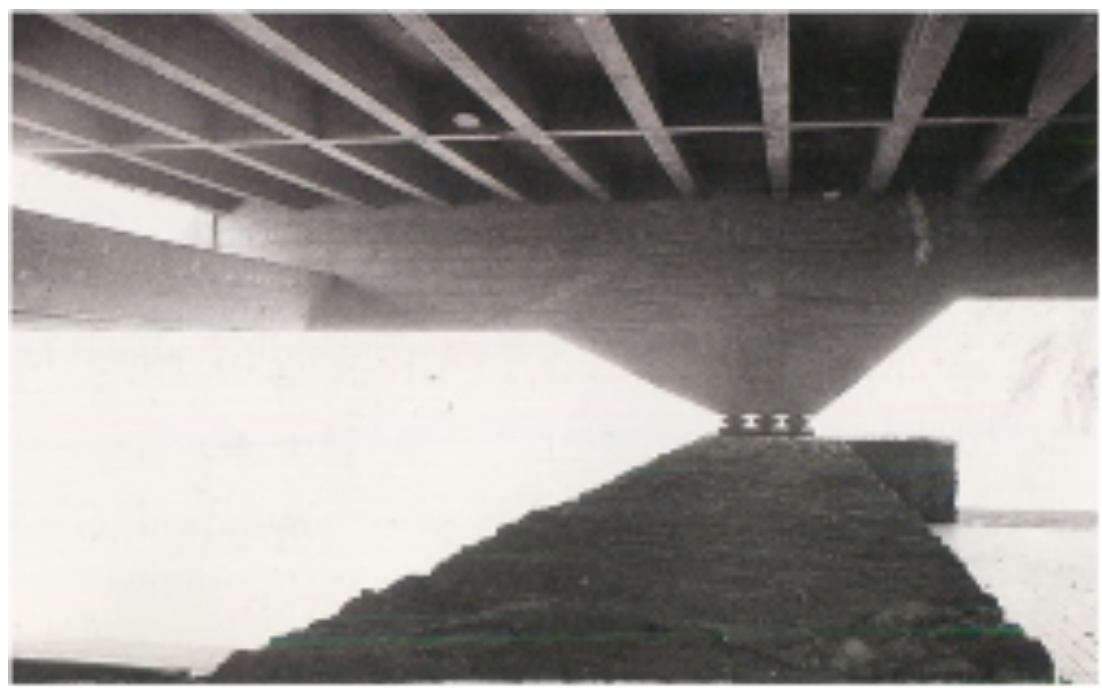

Fonte: Fundação Vilanova Artigas.

Nas obras da maturidade profissional de Artigas, modificações e inversões se patenteiam: de um lado, a fusão da estrutura com a geração de espaço interior da edificação, antes de contradizer, intensifica o preceito de Schopenhauer em separar claramente o suporte e o que é suportado, o que Artigas fazia em benefício da aparência de peso; de outro, a evidenciação do artifício estrutural apontava para a arquitetura como a apresentação estética do drama humano, objetivação estética de uma ideia de grau superior como aquelas que Schopenhauer assinalava às formas de representação do caráter e das ações humanas; pois o quê, senão o trabalho humano, arrancaria do solo pedras e com elas ergueria estruturas? Schopenhauer concebia o mundo humano como uma continuação intensificada, até mesmo na capacidade de sentir dor, da natureza, ou seja, o grau superior de objetivação da vontade a repousar, como o topo de uma pirâmide, sobre a base de todos os graus inferiores da natureza animal, vegetal e mineral. 


\section{Métodos de composição arquitetônica}

O grande vão, a realização moderna da engenharia por excelência, articulava-se com outros dois aspectos da pesquisa que Artigas desenvolvera no período até 1953. Tratava-se da geração de espaços pela extrusão de uma seção transversal ao longo de um eixo, em cujas extremidades o corte tornavase a fachada, deixando ver o partido do projeto no aspecto estético, bem como no da organização. Assim era na rodoviária de Londrina, na casa de Artigas e na Casa Julian Czapsky ambas em São Paulo. O outro aspecto, que é derivado desse primeiro, é a geração de espaços pela repetição de um padrão estrutural a intervalos regulares que, desde o Estádio do Morumbi como já mostrado anteriormente nas figuras 3 e 4, adquiriu o caráter de elaborado conceito de engenharia. Este padrão, visível no interior e nas extremidades da série, mostrava didaticamente a elaboração da estrutura, sem qualquer mistério, como uma ação humana sobre as coisas, e é por isso que nas extremidades da série, tornava-se a representação num plano. É o que se vê em obras como o Ginásio de Itanhaém (1959), no Ginásio de Guarulhos (1960), no Anhembi Tênis Clube (1961), na Garagem de Barcos do Santa Paula Iate Clube (1961) no estádio da Portuguesa de Desportos (1962), na Rodoviária de Jaú (1973) e no Laboratório Nacional de Referência Animal (1975), por exemplo. Já o intervalo entre ocorrências não era menos determinado por decisões bem visíveis, como a dimensão de salas de aula nos ginásios de Itanhaém e Guarulhos, ou então por uma razão estrutural ótima entre os vãos nos dois planos, como na colônia de férias dos trabalhadores têxteis (1969).

Mas qual o sentido desse didatismo? Há uma passagem, um fragmento de uma frase de Brecht que Artigas (1960/1975a, p. 4) destacava “[...] não mostrem muito, mas mostrem alguma coisa. E deixai que observem. Não se trata de mágica, mas de trabalho, meus amigos. [...].” Se isto pode nos pôr de acordo sobre o que Artigas tenha mostrado, o que exatamente ele não mostrou? As decisões bem à mostra eram aquelas do bem construir, do correto e do sábio uso dos materiais e da técnica, portanto, o trabalho em sua imanência deslocava totalmente a transcendência. Porém, há um excesso que não cabe na "moral construtiva”. Na garagem de barcos há um excesso enorme, excesso material, excesso tecnológico, excesso de contrastes de luz e sombra, excesso táctil de uma massa de concreto bruta tão evidenciada diante de um programa tão singelo.

O que está claro e inequivocamente mostrado é o bem construir, aquele 
nivelamento técnico alto que permite que o cidadão individual assuma um papel na sociedade ou na cadeia produtiva. Mas, e o excesso, o vão excessivamente grande, o grande vão em sua dimensão simbólica? Ainda no Santa Paula Iate Clube, por que tão virtuosístico estreitamento da área de apoio a seções quase pontuais (Fig. 8)?

\section{Símbolos arquitetônicos}

Nos parágrafos finais de “O Desenho” podemos ler:
A arte não é um símbolo, como supõem os filósofos da frustração. Os símbolos são frases, ou se quiserem, são versos que compõem o poema. Para os arquitetos da atualidade, é importante que se exprimam com símbolos novos. Os novos símbolos são irmãos das novas técnicas e filhos dos velhos símbolos (ARTIGAS, 1986, p. 52).

Da austera volumetria das suas obras, destacam-se os pontos de apoio como um momento, por vezes demasiadamente elaborado, onde o arquiteto como que parecia pretender emitir comentários de arremate, fazer declarações. Em suas obras os pontos de apoio recorrentemente assumem configurações assemelhadas a pirâmides ou a representações de pirâmides em baixo relevo, evidentes em obras como o Anhembi Tênis

Figura 9 - Vilanova Artigas. Estação Rodoviária de Jaú-acesso nordeste (1973)

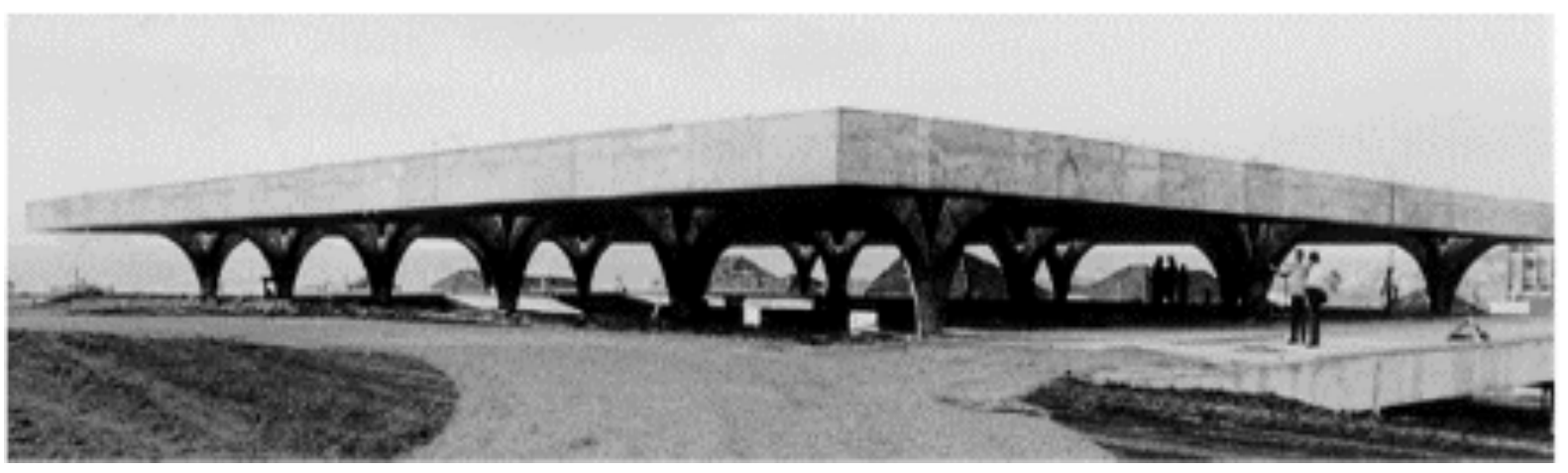

Fonte: Fundação Vilanova Artigas. 
Figura 10 - Vilanova Artigas. Estação Rodoviária de Jaú-seções transversal e longitudinal (1973)

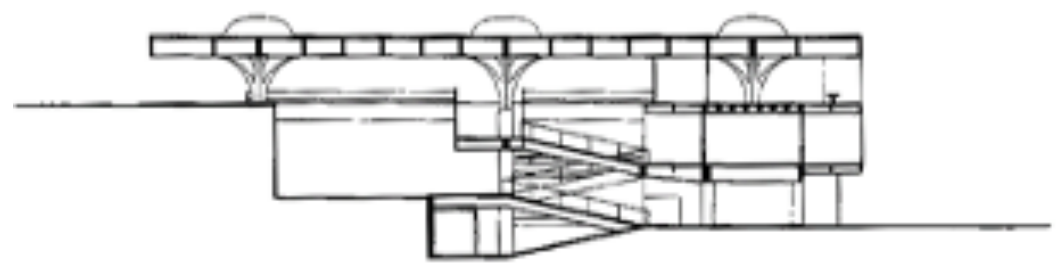

CORTE TRANSVEASAL

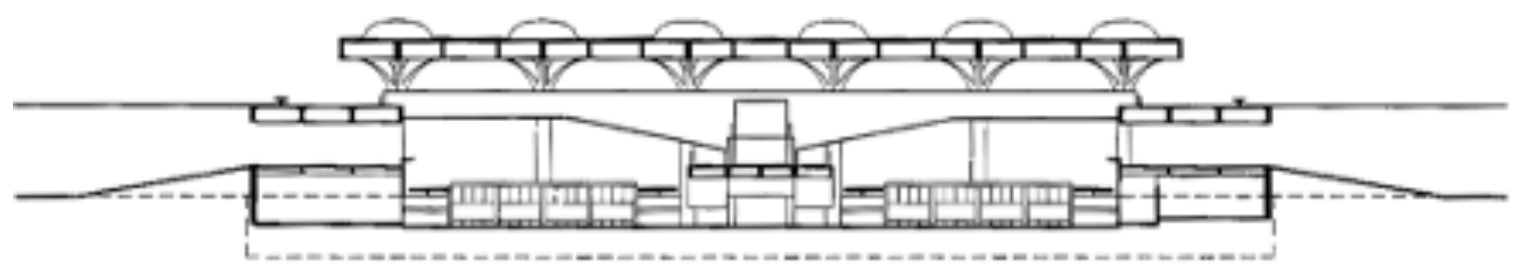

CORTE LONGITUONA.

Fonte: Fundação Vilanova Artigas.

Figura 11 - Vilanova Artigas. Estação Rodoviária de Jaú - acesso nordeste (1973)

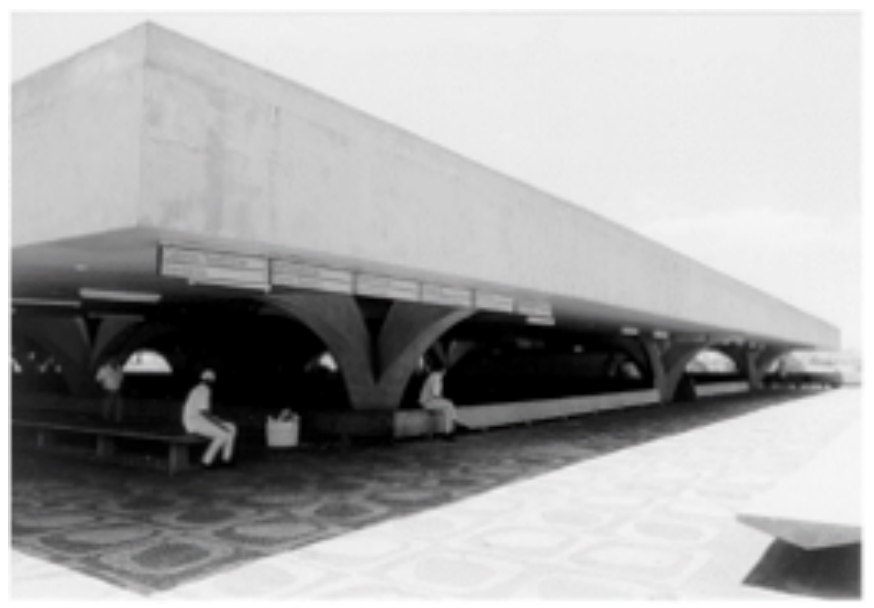

Fonte: Acervo do autor.

Figura 12 - Vilanova Artigas. Estação Rodoviária de Jaú - belvedere sudoeste (1973)

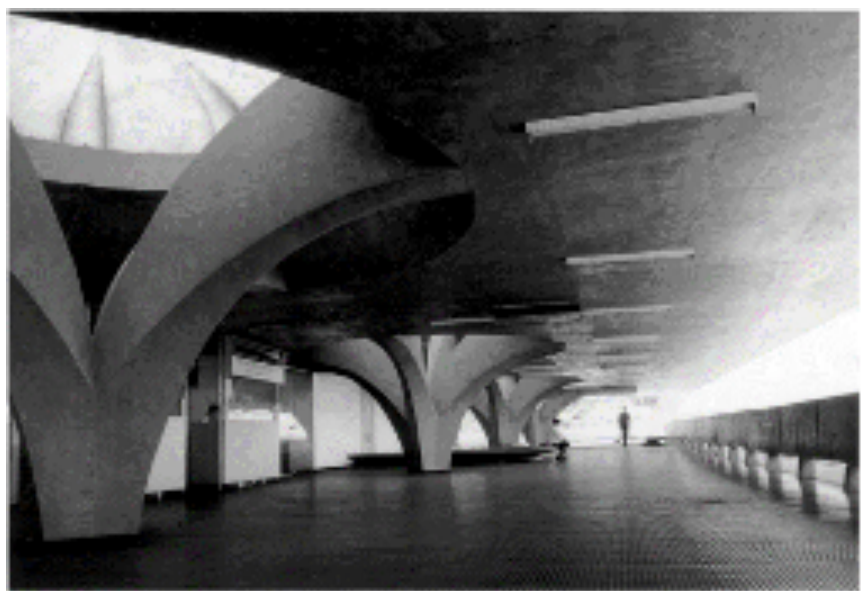

Fonte: Acervo do autor.

Antíteses, Londrina, v.13, n. 25, p. 447-481, jan-jun. 2020 \} 463 
Figura 13 - Vilanova Artigas. Estação Rodoviária de Jaú - belvedere sudoeste (1973)

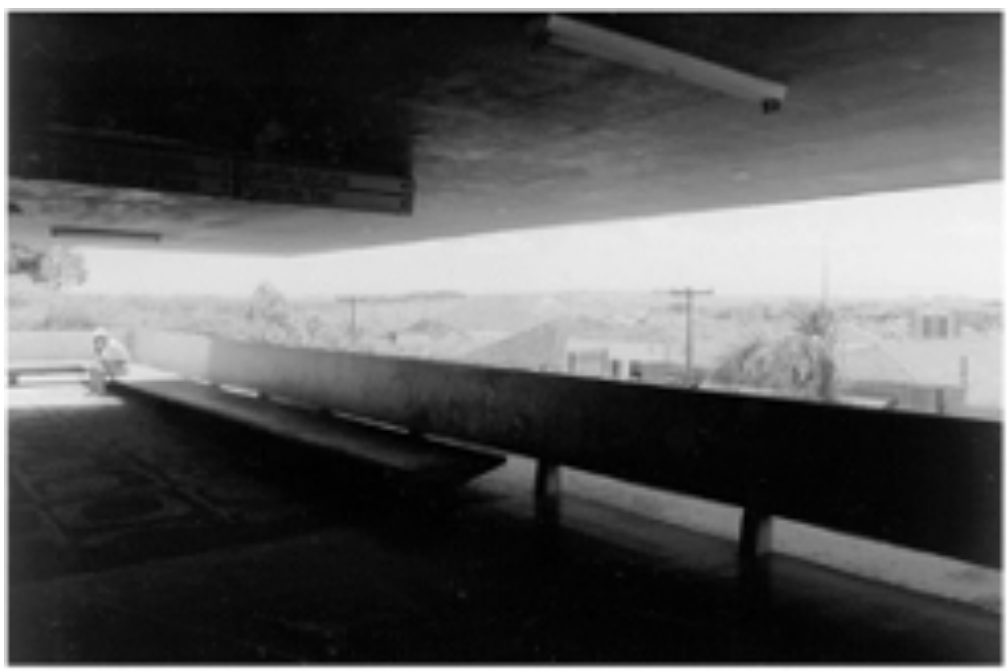

Fonte: Acervo do autor.

Figura 14 - Vilanova Artigas. Estação Rodoviária de Jaú - elevação sudoeste (1973)

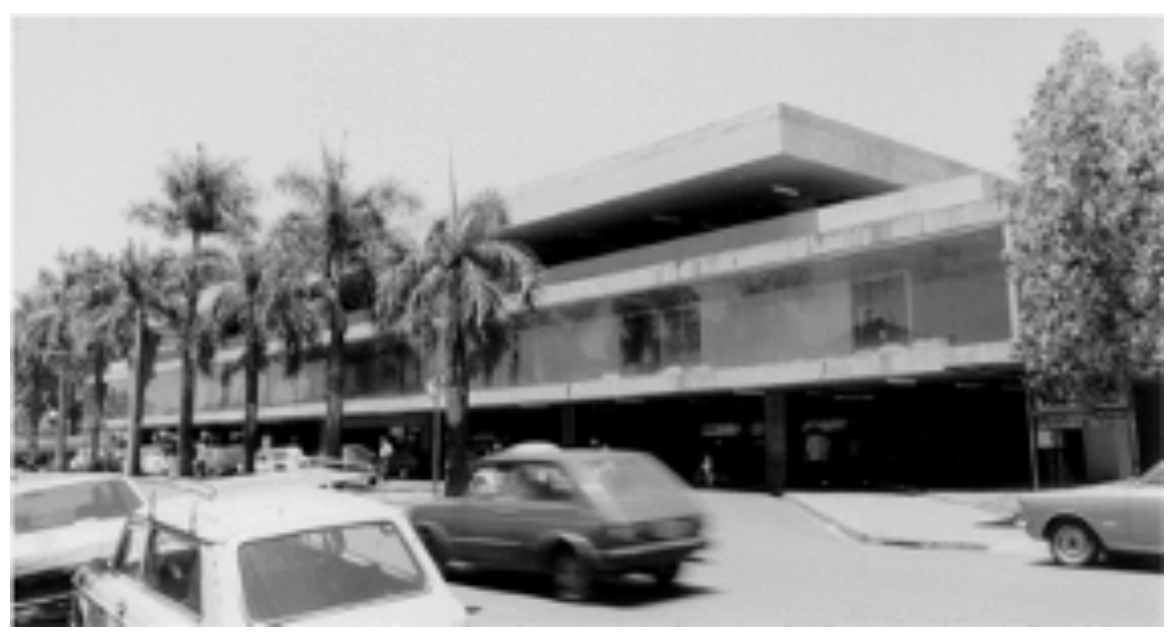

Fonte: Acervo do autor.

Clube, o Santa Paula Iate Clube, o L.A.N.A.R.A., a residência Mendes André, os vestiários do São Paulo Futebol Clube, etc. No prédio da FAUUSP são formas piramidais mesmo, algo já observado por Flávio Motta (1960). Tratava-se de compor formas triangulares em dois planos ortogonais no espaço de modo a absorver os momentos fletores na própria estrutura, e, assim, conduzir as cargas a uma área de apoio mínima sobre as fundações, um ponto, o vértice da pirâmide, que resiste por ser solicitada somente a compressão (momento nulo). A transmissão das cargas às fundações se fazia, às vezes, por rótulas, uma inovação tecnológica ${ }^{4}$ surgida na construção de pontes e que Artigas usava para evidenciar tanto o artifício, quanto a virtualidade do ponto de apoio. 
Corre de par com essa elaboração estrutural dos pontos de apoio a sua elaboração plástica, quer como representação da pirâmide em baixo relevo, como no Santa Paula Iate Clube ou nos vestiários do S.P.F.C., quer quando eles adquirem uma maior consistência volumétrica, inclusive com vazios escavados em sua massa, como no Anhembi Tênis Clube ou no Centro Educacional de Jaú. Essa elaboração é tipicamente escultórica, mas aqui é aplicada à arquitetura sem conflito, contudo, com a função estrutural. Este momento escultórico não era meramente postiço à parte propriamente arquitetônica, ao contrário do que pensava Schopenhauer $(1969$, v. 2), para quem a escultura arquitetônica se fazia em detrimento da apresentação clara e distinta do conflito estrutural. Pode-se mesmo observar em alguns casos, como no prédio da FAUUSP, a forma com que Artigas conduzia suas elaborações dos pontos de apoio de modo a convergir com a sugestão de Schopenhauer (1969, v. 2) de colunas em tronco cônico, com a seção reduzida sob o capitel, como mais expressivas da ação resistente, trazendo essa virtude expressiva para o apoio piramidal. Nas colunas periféricas do prédio da FAUUSP, os blocos de fundação que distribuem as cargas sobre estacas, projetam-se para cima da terra, ganham expressão visível, formando a pirâmide até a seção mínima de apoio na interseção com o prolongamento triangular da empena superior, acima da qual permanece e atinge o vértice apenas como relevo. Aquela seção reduzida é o ponto de momento fletor zero da estrutura. Seriam, então, elaborações de forma e estrutura desse tipo o que levava Artigas a falar, de modo ambicioso, de um "conflito entre a arte e a técnica [...] um conflito que não separa mas une [...]”? (ARTIGAS, 1986, p. 43). Essa escultura integrada às operações estruturais torna inteligível a surpreendente franqueza com que Artigas admitia sua disposição à pesquisa artística à qual ninguém dava ouvidos:

Claro que não pretendo reintegrar qualquer cariátide nas formas modernas. Elas que fiquem onde estão, símbolos de um humanismo admirável. Levanto com este dizer, a crítica ao lado ilegítimo desta origem da arquitetura moderna, quando se entregou a um utilitarismo imobilista. Em termos de cultura, nega o cultural inevitavelmente. [...] A criação de uma simbologia radicada profundamente na história do saber humano já começou a dar os primeiros frutos. Não quero exemplificar. Mas que percebam-no os olhos mais sagazes. [...]. Há um campo de pesquisa artística para a arquitetura, a meu ver inesgotável. [...] (ARTIGAS, 1967, p. 43). 
Mas qual o sentido dessas representações escultóricas de pirâmides, com frequência um tanto postiças? Do ponto de vista da história da técnica construtiva, recaímos nos egípcios, os mais notáveis construtores de pirâmides, que uniam a forma mais estável, a pirâmide, à alvenaria de pedra calcária, resistente somente à compressão, de modo a conferir à estrutura tanto mais estabilidade, quanto mais se lhe acumulasse a massa. Os pilares-pirâmide de Artigas invertem as propriedades estruturais dessa forma, comutando a simples compressão pela performance versátil do concreto armado.

O simbolismo da pirâmide invertida já aparecia na arquitetura de Oscar Niemeyer no Museu de Arte Contemporânea de Caracas. Projetado em 1954 e nunca construído, este museu foi concebido segundo o partido de uma pirâmide invertida no alto de uma encosta a dominar a paisagem do vale onde a cidade se espalhava. No plano simbólico, aquele volume é uma montanha artificial; a pedra só resiste à compressão, mas a tecnologia moderna do concreto armado e protendido resiste à flexão e torna possível a pirâmide invertida, nesse caso, um símbolo do soerguer-se da obra humana para além e negando a natureza. Aquele projeto era tão comprometido com esse simbolismo que sacrificava as amplas visuais que poderiam ser franqueadas pela implantação numa encosta elevada que dominava toda a cidade, em favor de um volume plástico cerrado, quase sem aberturas.

Algumas das representações invertidas de pirâmides em obras de Artigas aparecem, como no Anhembi Tênis Clube ou no Centro Educacional de Jaú, com um espaço escavado nelas, lembram as palavras de Motta (1960, p. 67): “o que esse arquiteto procura é a expressão da energia que penetra a matéria com vigor e a obstinação de quem não impõe limites ao espaço, mas escava um oco para o homem.” Suas pirâmides, quando não tem um espaço escavado ou o vértice para baixo, comparecem como ornamentos sobre os apoios, os quais são realizações técnicas que proporcionam um máximo de espaço vital, o vão livre, com o concurso da ciência. Sobretudo, nos parece que representam a inversão do sentido da transcendência para a imanência do trabalho. Mas isso se dá como expressão simbólica laudatória da utopia da técnica ou da organização moderna do trabalho? Ou haveria algo mais?

\section{Imagens do sublime arquitetônico}

Outros aspectos do partido típico de projeto apresentam imagens da ordem do sublime, esse modo de enervação estética de tom grave e moralmente 
elevado. Trata-se de procedimentos de composição conectados com conceder proporções volumétricas à estrutura ou a fundi-la com a definição volumétrica pelo uso das empenas, o que já caracterizamos como hipérbole. É o que se dá com a definição de volumes muito individualizados e cerrados, sem janelas ou quaisquer aberturas que lhes diminuíssem o sentido de solidez e massa. Se no aspecto exterior se apresentam como massas é porque a visão ou quaisquer sinais do espaço aberto que contenham são evitados. Do interior, toda visão do exterior que situe o corpo da edificação é negada, o que acentua o espaço interno por hipérbole.

Essa alternância no percurso fora-dentro se dá entre o momento da coisa ou volume e o momento do espaço. Interessa aqui o comércio entre literatura ou teoria e a fatura das formas artísticas da arquitetura. Qual o sentido na obra de Artigas da alternância entre solidez e aparência de peso e o espaço? Mas há ainda outras alternâncias a observar. A fusão da estrutura aparente com a definição volumétrica de espaços interiores ou meramente o espessamento volumétrico da estrutura, como já vimos, apresenta de modo ampliado, e até ilusionista, o conflito peso-resistência; sendo os apoios do tipo pilotis, se estabelece o contraste entre o volume, a massa e a frontalidade sob a luz e o espaço fluindo por debaixo na obscuridade ou nas meias luzes em profundidade. Esse contraste é constitutivo da apresentação clara, distinta e veemente das massas sobre pontos de apoio largamente espaçados. O material único, o concreto deixado aparente com as marcas das formas de madeira, opera a fusão das partes e representa hiperbolicamente peso, massa, gravidade e materialidade.

As notas de Burke (1996, p. 84) sobre o sublime nas obras arquitetônicas enumeram certas figuras aqui identificáveis:

[...] o sublime que resulta da repetição, sucessão e uniformidade a perder de vista, em profundas visuais; os ambientes escuros e sombrios e as luzes intensas que subjugam a visão, uma transição brusca da luz para as trevas, ou destas para a luz, causa um efeito ainda maior. Mas as trevas são mais fecundas de ideias sublimes do que a luz.

\section{Um passeio pelo prédio da FAUUSP}

Um passeio pelo prédio da FAUUSP (Fig. 15-19) pode mostrar como se dá a alternância entre os modos do espaço/treva/vão e da coisa/massa/luz/ frontalidade. Ao aproximarmo-nos do prédio pelo sul (Fig. 16), as superfícies 
externas são contrastadas com a obscuridade sob o pilotis. A massa, suspensa sobre os apoios periféricos, faz-se perceber com toda veemência quando já estamos sob ela (Fig. 17). Subimos alguns degraus na base e vamos para debaixo do volume da biblioteca, para um pé direito reduzido bruscamente à metade e em maior obscuridade; nessa transição volumétrica brusca, a laje de concreto como que comprime o espaço em que caminhamos até nova e mais brusca transição, para o salão central intensamente iluminado pela grelha de domos da cobertura, num pé direito dilatado agora cinco vezes maior que o precedente (Fig. 18). Caminhando pelo salão central, olhando para trás vemos o exterior e a vegetação intensamente iluminados em pleno sol. Tudo o que está ou se move na obscuridade sob o volume da biblioteca fica reduzido a uma silhueta escura contra a luz intensa (Fig. 18 e 19). Viramo-nos e continuamos olhando para cima, para a sucessão uniforme a perder-se de vista da grelha de domos da cobertura, formada volumetricamente por troncos de pirâmides vazados.

No salão central destaca-se o volume em balanço do atelier multidisciplinar (Fig. 18), volume alongado na horizontal e totalmente cerrado, monolítico, todo de concreto sem juntas ou aberturas a denunciar o oco. Se subirmos as rampas, mergulhamos novamente na obscuridade, mas descortinamos todo o espetáculo descrito no percurso anterior. Por outro lado, vista de outras posições, a bateria de rampas faz as vezes de uma fachada interna que mostra a articulação dos níveis alternados com clareza diagramática.

O prédio da FAUUSP é composto também, ainda que de modo menos evidente, por um padrão estrutural que se repete ao longo do eixo leste-oeste. As elevações nas extremidades desse eixo não mostram o corte diagramático, entretanto repetem as empenas e as colunas das faces norte e sul que, pela alternância das linhas de apoios, faz com que os cantos do edifício formem balanços muito salientes (Fig. 16). De todas essas operações resulta que o aspecto exterior do prédio assemelhe-se a uma grande rocha, um dólmen talvez, o que se repete com o volume interno do atelier multidisciplinar em balanço sobre o salão central. Se admitirmos o aspecto antropomórfico das colunas periféricas do prédio, que Artigas chamava de cariátides, o aspecto geral é de um cortejo fúnebre, de indivíduos que caminham carregando um corpo morto na horizontal ${ }^{5}$. 
Figura 15 - Vilanova Artigas. Edifício da Faculdade de Arquitetura e Urbanismo da USP elevação norte (1961)

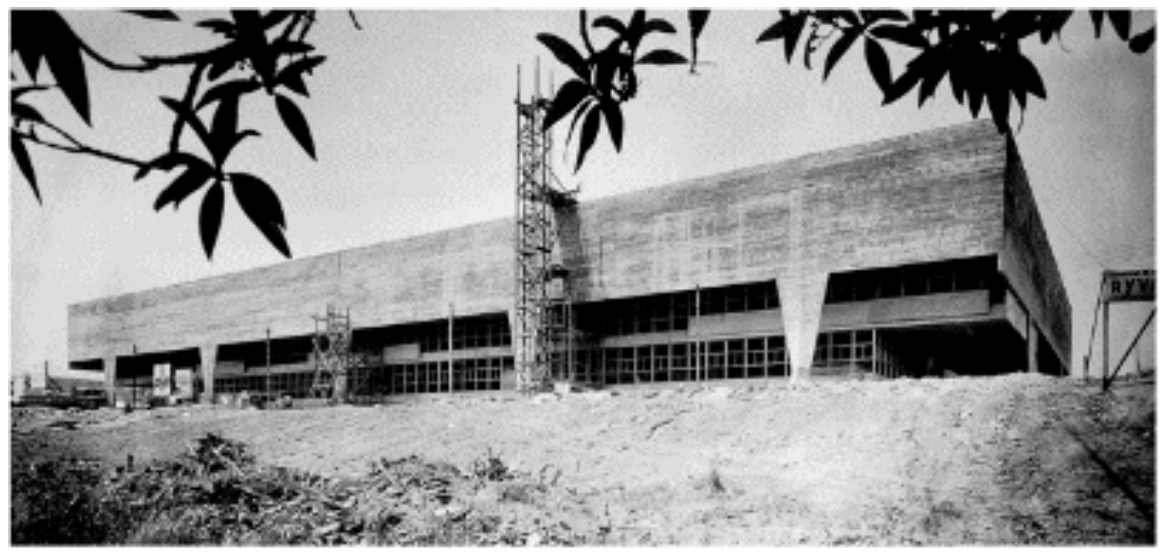

Fonte: Fundação Vilanova Artigas.

Figura 16 - Vilanova Artigas. Edifício da Faculdade de Arquitetura e Urbanismo da USP canto sudeste (1961)

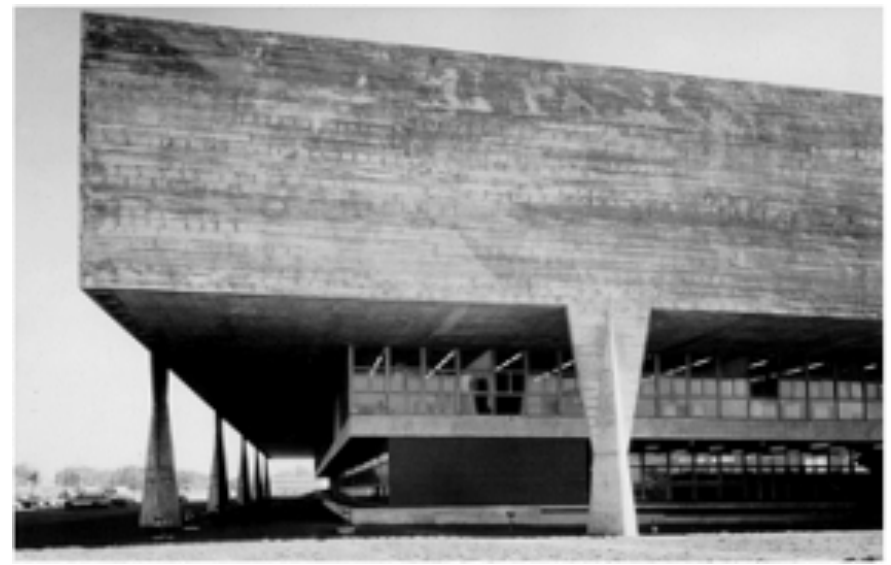

Fonte: Fundação Vilanova Artigas.

Figura 17 - Vilanova Artigas. Edifício da Faculdade de Arquitetura e Urbanismo da USP acesso principal pelo sul (1961)

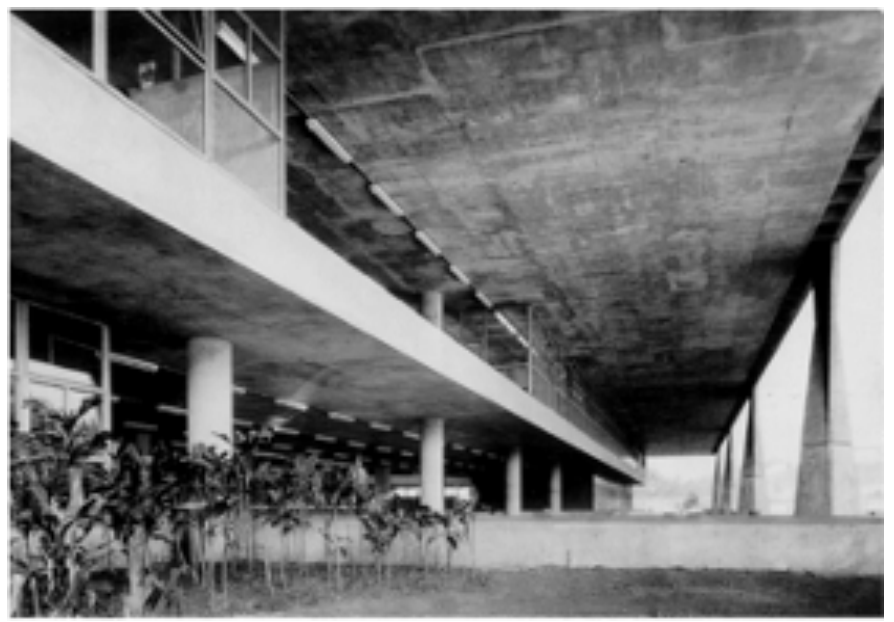

Fonte: Fundação Vilanova Artigas. 
Figura 18 - Vilanova Artigas. Edifício da Faculdade de Arquitetura e Urbanismo da USP salão no centro do edifício (1961)

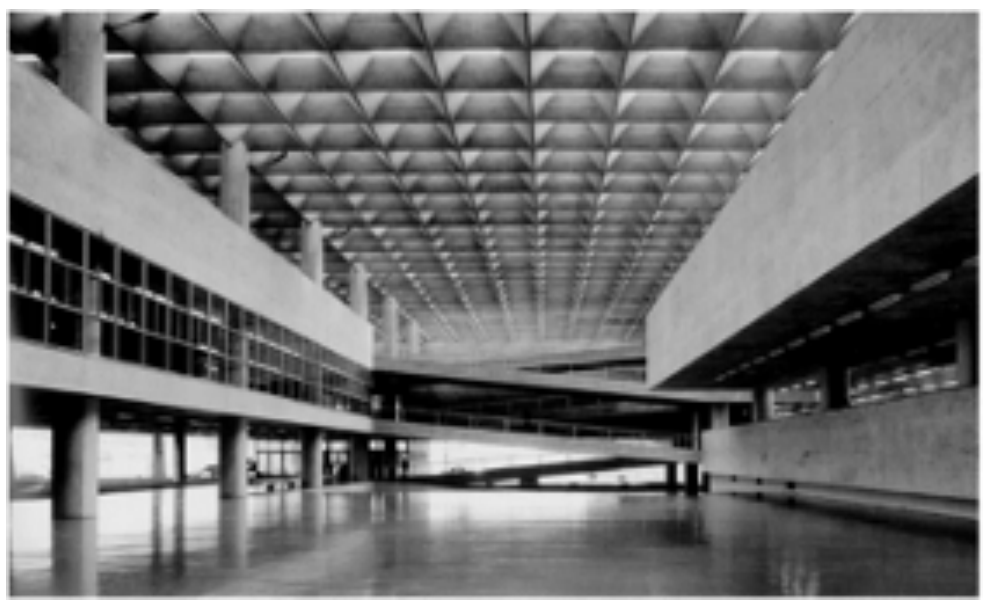

Fonte: Fundação Vilanova Artigas.

A esse propósito mais uma figura do sublime, segundo Burke (1996, p. 84), pode ser evocada:

\begin{abstract}
Uma outra fonte de gravidade é a dificuldade. Quando uma obra parece ter exigido uma força e um trabalho imensos para realizá-la, a ideia é magnífica. Stonehenge não é admirável pela disposição nem pelo ordenamento, mas aquela reunião de enormes pedras em estado bruto postas em pé e empilhadas suscita no espírito a ideia de uma força prodigiosa exigida para tal obra. Ademais sua rusticidade reforça essa causa de grandiosidade, assim como exclui a ideia de arte e invenção, pois a habilidade produz um outro tipo de efeito, bastante diverso deste.
\end{abstract}

Para Burke (1996), o sublime era uma enervação pelas representações de dor e perigo derivadas das paixões relativas à autopreservação, mas como representações somente, sem que se estivesse exposto à dor e ao perigo. Estar sob uma grande massa apoiada sobre afastados e minúsculos pontos de apoio suscitaria, então, esse tipo de enervação estética. O trabalho da construção, com máquinas e pesos enormes sendo elevados ou movidos, suscita assombro, admiração, reverência e respeito porque "nada do que é perigoso pode ser considerado insignificante ou desprezível”. A mera visão de trabalhadores em meio às máquinas, aos pesos e às pedras suscita já temor, o pressentimento da morte. 
Figura 19 - Vilanova Artigas. Edifício da Faculdade de Arquitetura e Urbanismo da USP salão no centro do edifício (1961)

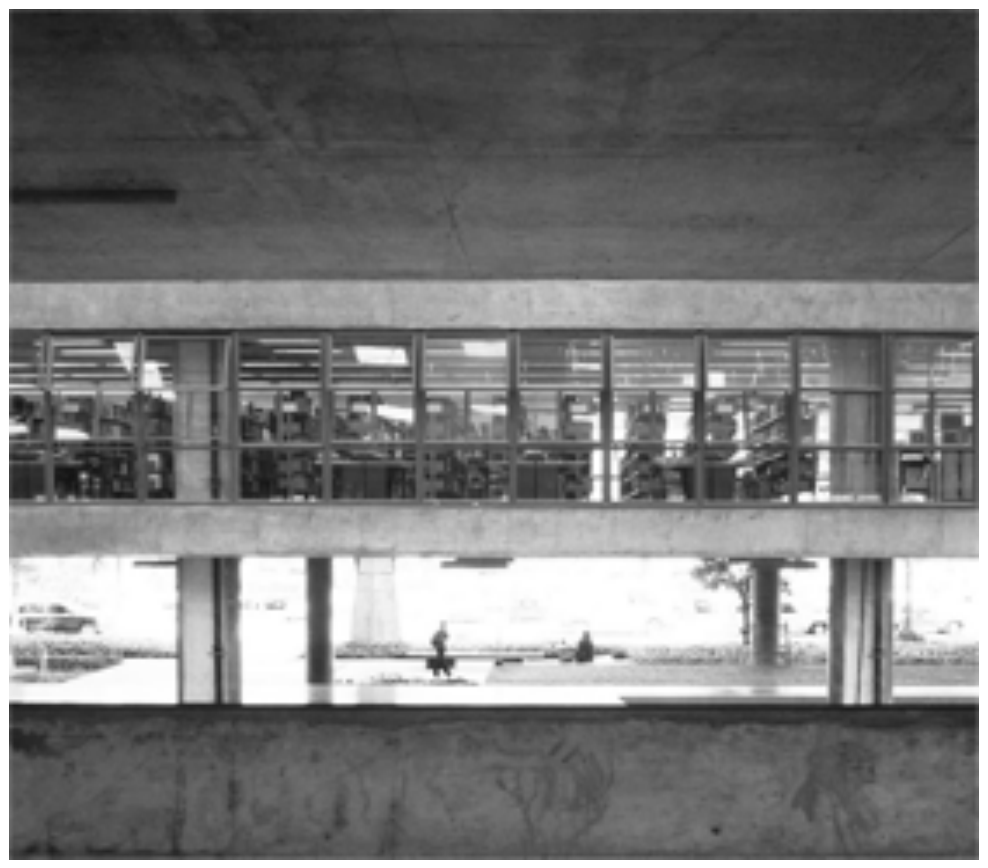

Fonte: Acervo do autor.

Podemos, portanto, distinguir já o temor, por remoto que seja, ou o pressentimento da morte, como fonte genuína do sublime. Outro sentido é o da admiração diante da habilidade, da capacidade de, sendo fraco, tirar partido de circunstâncias favoráveis para dobrar forças prodigiosas à sua vontade. Esse sentido é o da astúcia, já tão conhecido pelos gregos, e é dele que falava Vitrúvio (1999, p. 220) a respeito de guindastes: “[...]. Tratora, por sua vez, é o gênero de máquinas no qual um peso é elevado por meio de guindastes a fim de que seja colocado nos locais mais elevados. As máquinas elevatórias devem ser admiradas não como obras de arte, mas de audácia. [...].”

Mesmo que se leve em conta que o sentido da arte ou obra de arte certamente difere em Vitrúvio (1999) e Burke (1996), a distinção da audácia ou astúcia do fraco e pequeno conduzindo forças colossais segundo seus propósitos, como um sentido específico já estava configurado muito antes do tratadista romano.

Em Eupalinos (VALÉRY, 1996), no diálogo entre fantasmas, Fedro indagava se as paixões que impelem os homens a seus empreendimentos os pudessem levar a produzir qualquer coisa que escapasse à voragem natural: 
destinos decidiram que, entre as coisas indispensáveis à raça humana, figurassem alguns desejos insensatos. Não haveria homens sem o amor. Nem a ciência sem absurdas ambições. E de onde pensas que tenhamos extraído a primeira ideia e energia para os esforços imensos que erigiram numerosas cidades tão ilustres e tantos monumentos inúteis que, embora incapaz de os conceber, a razão admira? FEDRO: Mas a razão, de algum modo participou, sem ela, tudo estaria por terra. SÓCRATES: Tudo (VALÉRY, 1996, p. 26).

Segundo Schopenhauer (1969, v. 1) cada desejo ou necessidade é saciável, porém o animal homem é insaciável, pois a cada desejo saciado segue-se um outro a exigir satisfação tão tiranicamente quanto o anterior, e assim até que a morte tudo pacifique. Que dizer de nosso dourado sonho moderno de dominação técnica irrestrita da natureza que promete mais que a satisfação animal, promete a superação da condição animal num reino de liberdade e racionalidade, este sim humano? A arte de construir abrigos e proporcionar conforto e proteção encontra nas imagens do perigo e da morte, nas imagens de lápides e cortejos fúnebres, de escuridões e luzes ofuscantes, um testemunho autêntico de tudo que transcorre na construção, do destino que zomba de nossa crença simplória na domesticação da natureza e da habilidade de que tanto nos gabamos. Essa arte, contudo, não é apenas o monte de entulhos de Schopenhauer (1969, v. 1, p. 214) a zombar de nós. Os prédios estão aí de pé e firmes, bem proporcionados, belos nos seus materiais, nos espetáculos que emolduram e nos levam a descortinar. Sob os balanços e vãos colossais, às luzes e sombras intensas, e à sugestão de imagens aterradoras, conduzimos nossos afazeres cotidianos, alheios a essas imagens, que estão, contudo, aí, sempre que estivermos disponíveis, em momentos contemplativos entre um interesse e outro.

\section{Considerações Finais}

O drama do trabalho da construção, para o qual Artigas deu ou pretendeu ter dado expressão artística, é intrinsecamente ambíguo. Se o entendermos através daquela passagem de Artigas que já citamos acima: "Do sofrimento do nosso povo, posso dizer que participei profundamente. Alguém terá olhos para, um dia, ler nas formas que projetei, todo esse sofrimento. Se verá uma poética traduzida" (ARTIGAS, 1997, p. 28), ele pode muito bem ser compreendido 
através do marxismo tradicional como momento da exploração do trabalho; a biografia do marxista Artigas suporta esta conclusão.

Já pela via de Schopenhauer (1969, v.1, 2), o conflito entre o peso e a resistência deu outra feição ao drama do trabalho, a incorporação do insaciável e do não razoável da vontade, bem como envolveu uma promoção superior das possibilidades estéticas da arquitetura. Por esta via veio à tona algo de trágico no trabalho, algo que a modernidade reluta em dar-se conta e que denuncia o milenarismo da sociedade moderna do trabalho. As figuras do sublime tanto acrescentam ênfase ao que há de desarrazoado no esforço do trabalho, quanto fazem vir à tona alguns outros sentidos, como a astúcia de que a técnica moderna se gaba. O trabalho e a construção não apenas mexem com o insaciável, mexem também com desejos totalmente não razoáveis, o que nos conduz às antípodas do pensamento marxista do trabalho e da racionalidade moderna.

O trágico a que nos referimos acima pode muito bem ser discutido como entre o excesso e a beleza artística pela qual salvamo-nos do niilismo, o que já desloca a questão para o signo do eterno retorno. Este último, dá um sentido positivo para o esforço artístico, mesmo que sob a forma extrema de mover pesos incalculáveis. Se o prédio que nos abriga mostra-se ao fim como orientado a satisfazer algum desejo “absurdo”, não exijamos nós que seja puramente utilitário, permitamos que nos momentos de contemplação se mostre de outro modo.

A compreensão socialista e a trágica representam o devir da modernidade de modos diversos. A visão marxista o representa como séries do tempo histórico convergentes para com o desfecho revolucionário da total reconstrução emancipatória do organismo social. O ponto de vista de Gilles Deleuze (1990) e sua compreensão do eterno retorno, redesenharam a topologia do devir ou do tempo histórico da modernidade, reconhecendo-se plenamente que o fundamento, ou razão suficiente, tornou-se ausente. Como diria Hannah Arendt (1999), toda e qualquer ordem de valor pode, então, fechar-se numa série processológica, fechar-se porque não há referência àquilo que, não sendo um elo da série, lhe fosse transcendente, ou seja, o fundamento. Assim, representar o devir como séries convergentes quer na "transformação revolucionária”, quer no "progresso liberal”, enfim as grandes matrizes do pensamento político moderno, parece fazer referência a uma versão postiça e secularizada do fundamento em vez de haver-se com sua ausência. Ao contrário do que suas representações reconhecem, essas matrizes não podem senão proceder na forma de inumeráveis séries fechadas que não se relacionam por continuidade, 
mas por contato ou por compartilharem elos entre si. Afinal, não estamos aqui às voltas com obras que são concomitantemente elos das séries da engenharia e da arte conforme as abordemos?

O desprezo de Artigas pelas estruturas que imitassem as formas naturais ecoava, parece haver pouca dúvida, os escritos de Pedrosa sobre Brasília, em que o crítico opôs, como já o fizera em 1944 nos escritos sobre Calder, um espírito europeu a um americano. Este último caracterizava Brasília, uma cidade construída em meio a vasta região despovoada, construída como um oásis de uma cultura que lhe chegava já pronta a sobrepor-se a um deserto, como fora com o Egito e sua arte na antiguidade. Este processo de impor uma forma não responsiva ao ambiente era caracterizado por Pedrosa (1981d), como antinatural e profundamente americano: "americanos, brasileiros, estamos condenados ao moderno” e “aí está porque há algo no americano, no canadense, no argentino, no paulista, que é intrinsecamente antinatural” (PEDROSA, 1981d, p. 305). Em “A máquina, Calder, Léger e outros” (PEDROSA, 1949), este tema era desenvolvido e recebia um formato teleológico, isto é, o americanismo de Calder não era mera afirmação da superpotência mundial, era até mesmo crítico dela. Para Calder tratava-se de vencer o estranhamento entre a imaginação e o cosmo no interior da própria técnica, na atividade produtiva. A imaginação procederia por abandonar a naturalização ornamental da forma dos objetos em favor de uma formalização abstrata na qual se daria uma identidade entre seus princípios de forma e aquelas do cosmo, as leis do cosmo. Assim as formas de Brasília, não respectivas da região, seriam, contudo, afins a leis de uma esfera mais alta de abstração. $\mathrm{O}$ aspecto teleológico ou utópico consistia na transformação da natureza pela técnica até que ambas se tornassem uma só, ou seja, séries temporais convergentes num certo tipo de emancipação da humanidade.

A obra de Artigas revela, enquanto obra, algo diverso deste pensamento de Pedrosa que lhe era talvez a referência. No período logo após a inauguração de Brasília, a "utopia Brasília” já havia desvanecido completamente na "Brasília dos políticos profissionais e suas agendas”. Não é à toa que no congresso de críticos de arte de 1961, Pedrosa (1961) já abandonava a arquitetura obra de arte que formulara para a Capital Federal, pois a sociedade não lhe parecia caminhar para a síntese entre a arte e a satisfação das necessidades coletivas, uma síntese que era a substância mesma de sua proposição da integração das artes.

Em “A bienal de cá para lá”, Pedrosa (2015b) denunciaria, uma década mais 
tarde, a arquitetura obra de arte como ideologia, chamando os arquitetos à tarefa de fazer da arquitetura uma ciência. Levaria algum tempo até que o relacionamento entre arquitetura e arte, como em Niemeyer, Artigas e tantos outros, se deslocasse para novos interesses, uma mudança de registro tal que quando levantamos a questão que está no centro deste trabalho pela primeira vez em $1998^{\circ}$, ela havia se tornado um tanto deslocada. Além disso, a síntese ou integração das artes de Pedrosa tinha como finalidade a criação de um "estilo da modernidade” (PEDROSA, 1964, 2015a), uma proposição em face da qual é que podemos começar a compreender a arquitetura obra de arte de Artigas, criada na surdina senão na clandestinidade mesmo, pois seu silêncio lhe era possivelmente autorizado pela crença bastante frequente em que os estilos do passado se difundiam por imitação e não pela mediação do discurso crítico.

Mais recentemente testemunhas se manifestaram dando conta de que criar um "estilo da modernidade", a arquitetura paulista, havia mesmo sido o fim a que se dedicara Artigas. Contudo, estaríamos muito equivocados se considerássemos que isto encerra a questão, pois o tema de reconhecer numa obra arquitetônica moderna uma obra de arte, pode ser feito de forma a suscitar no público profissional não apenas ceticismo, mas uma formidável resistência. A comunidade atual dos profissionais e acadêmicos da arquitetura não está bem sintonizada com as disciplinas que permitem fazer crítica de arte da arquitetura. É comum flagrar manifestações de encanto e admiração pelas obras de F. L. Wright, Mies van der Rohe e Le Corbusier, sobre as quais há alguma literatura que pelo menos destaca as percepções estéticas que suscitam e lhes dá precisão. Mas este discurso pouco penetra e se difunde, terminando em admiração pelo que foi um dia possível e não voltará mais. Além disso, o formato de nossos institutos universitários, as Faculdades de Arquitetura e Urbanismo, compreende tantos interesses diversos, legítimos, mas em disputa pelo poder institucional, que o espaço para investigações delicadas e minoritárias talvez termine muito reduzido, se é que reste algum.

No ambiente internacional, contudo, o historiador da arquitetura britânico Anthony Vidler vem há mais de duas décadas abordando a questão frontalmente através do conceito do architectural uncanny. Uncanny é o equivalente inglês, ou quase, ao termo alemão unheimlich, expressão com a qual Freud (1964) fez uma sondagem psicanalítica no campo da literatura para revelar o sentimento do estranho que experimentamos quando complexos infantis reprimidos no processo de amadurecimento são revividos por alguma impressão ou quando nossas crenças primitivas, igualmente reprimidas, mas que nos parecem 
superadas, parecem ser confirmadas por alguma realidade física; de qualquer modo, o unheimlich é experimentado quando algo que deveria ser mantido oculto não obstante vem à luz. A procedência psicológica desse conceito recebe um formato histórico com Vidler: o conceito de um choque da modernidade que remonta ao sublime e ao terror nas artes e na literatura do séc. XVIII, o uncanny, entretanto que já conta com formidável e ininterrupta tradição:

\begin{abstract}
Adorno apoiava suas observações citando Freud e sua sentença de que o uncanny é uncanny somente porque é secretamente familiar, motivo pelo qual é reprimido. A familiaridade do estranhamento na arte moderna, concluía Adorno, oposta à distância da obra clássica, aparentemente familiar, era resultado da repressão mesma dos efeitos da arte moderna; sua negação por críticos modernos era um sinal de sua secreta acessibilidade (VIDLER, 1996, p. 9).
\end{abstract}

Assim restaurado à sua historicidade, o uncanny poderia ser entendido como uma resposta significativa, psicológica e estética, ao verdadeiro choque do moderno, um trauma que se tem composto com suas subsequentes repetições em escala mais ou menos terrível e que está longe de ter sido exorcizado do imaginário contemporâneo. Deste modo, a obra de Artigas e a estranheza que suscita enquanto obra de arte no público profissional, parece implicada, até bem demais, na questão do estranhamento do que seria de outro modo familiar. E assim passamos nossas vidas profissionais em seus edifícios, em seus espaços sublimes, e reclamamos sem cessar de sua eventual má performance em conforto térmico.

Contudo, aqui é ainda interessante uma contraposição de nossas observações sobre Artigas com a tese de Reyner Banham (1970) em "Teoria e Projeto na Primeira Era da Máquina”. Este autor partia do conceito de tecnologia colhido nos futuristas italianos ainda antes de 1920 e em Buckminster Fuller, um pouco depois: "[...] uma tendência desenfreada à mudança constantemente acelerada.” (BANHAM, 1970, p. 327). Este processo de mudança sem freio e sempre acelerada, mais do que conceito de uma modalidade determinada de atividade produtiva, a tecnologia, seria mesmo um conceito do tempo histórico. Similarmente, Hannah Arendt (1999) caracterizou a modernidade madura como o domínio do processo incessante. Segundo a autora, em outras épocas a atividade produtiva tinha um término que era o produto, dotado este de certa durabilidade e posto para o uso humano. Já na modernidade madura, 
a atividade produtiva não conhece a conclusão no produto, pelo que não há pausas e desvios. A atividade produtiva como processo ininterrupto faz do produto um elo necessitado de um consumidor para que o processo mesmo não seja interrompido, como nas crises cíclicas ou de superprodução. Banham argumentava $^{7}$ que num processo desse tipo, sem o produto como terminação, não poderia haver qualquer conceito de perfeição ou de obra de arte.

Num sistema produtivo em que o produto fosse uma terminação, as cadeias relacionais que envolvem todo o ambiente podiam se constituir de modo a apontar para um transcendental invisível, o qual seria o modelo invisível das produções dotadas de duração, ou seja, a terminação ou finalidade de toda a atividade produtiva. As obras primas, assim, seriam as produções que mais perto chegassem do modelo invisível, pois que este era o télos imanente ou entelekhéia das coisas visíveis. Compreende-se, então, que havia uma hierarquia entre as produções em que as obras mestras eram como que os modelos a serem imitados pela produção ordinária. Compreende-se, também, como no mundo moderno o estilo foi aos poucos se tornando coisa do passado, pois que este era da natureza da transcendência, a qual se retirou.

O ponto visado por Banham (1970) era a incompatibilidade entre a perfeição de obras como a Villa Savoye e o Pavilhão de Barcelona, e a tecnologia que era evocada para justificar a arquitetura moderna. O resultado desse "equívoco" teria sido a constituição do movimento moderno como um estilo da modernidade enquanto a tecnologia seguia rumo próprio e diverso. O texto de Banham, publicado em 1960, é objeto de muitos entendimentos diversos, entre os quais aquele que elimina a estética do horizonte da arquitetura, a qual deveria seguir a tecnologia tão logo o equívoco fosse desfeito.

A obra de Artigas nos sugere outra compreensão. A arquitetura esteticamente ambiciosa não é, nem pode ser, modelo de perfeição, mas pesquisa estética interessante, pois constitui séries diversas daquela da tecnologia e de sua tendência ao nivelamento demasiado. Assim, estas pesquisas já não têm que se justificar por serem veículos da tecnologia, mas por usarem a tecnologia em produções interessantes capazes de amplificação e capilaridade no ambiente da modernidade tardia.

\section{Referências}

ARENDT, Hannah. A condição humana. Rio de Janeiro: Forense Universitária, 1999. 
ARTIGAS, João Batista Vilanova. A função social do arquiteto. São Paulo: Nobel, 1989.

ARTIGAS, João Batista Vilanova. Argan e Nervi. [S. 1.: s. n.]: 1960/1975b. (Caderno de notas inédito do Acervo Fundação Vilanova Artigas).

ARTIGAS, João Batista Vilanova. Arquitetura - depoimento: o homem e a arquitetura. Casa e Jardim, São Paulo, n. 160, p. 42-48, abr. 1967.

ARTIGAS, João Batista Vilanova. O desenho. In: ARTIGAS, João Batista Vilanova. Caminhos da Arquitetura. São Paulo: Fundação Vilanova Artigas/Pini, 1986. p. 41-52.

ARTIGAS, João Batista Vilanova. Teoria da elasticidade. [S. 1.: s. n.]: 1960/1975a. (Caderno de notas inédito do Acervo Fundação Vilanova Artigas).

ARTIGAS, João Batista Vilanova. Vilanova Artigas. São Paulo: Instituto Lina Bo e P.M. Bardi: Fundação Vilanova Artigas, 1997. p. 15-33. (Edição de Depoimentos Gravados de Posse da Fundação Vilanova Artigas).

BANHAM, Reyner. Theory and design in the first machine age. New York: Praeger Publishers, 1970.

BURKE, Edmund. Uma investigação filosófica sobre a origem de nossas ideias do sublime e do belo. Campinas: Papirus, 1996.

BUZZAR, Miguel Antonio. João Batista Vilanova Artigas: elementos para a compreensão de um caminho da arquitetura brasileira 1938-1967. São Paulo: UNESP, 2014.

COLQUHOUN, Alan. Racionalismo: um conceito filosófico em arquitetura. In: COLQUHOUN, Alan. Modernidade e tradição clássica. São Paulo: Cosac \& Naify, 2004. p. 67-95.

CONGRESSO INTERNACIONAL EXTRAORDINÁRIO DE CRÍTICOS DE ARTE, 1959, São Paulo. Anais [...]. [Paris]: AICA/Unesco, 1959.

DELEUZE, Gilles. The logic of sense. Londres: The Athlone Press, 1990.

FREUD, S. The 'Uncanny'. In: FREUD, S. The standard edition of the complete psychological works of Sigmund Freud. Londres: The Hogarth Press and the Institute of Psychoanalysis, 1964. v. 17 (1917-1919), p. 217-256. An Infantile Neurosis and Other Works. Disponível em: www.arch.mcgill.ca/prof/bressani/ 
arch653/winter2010/Freud_TheUncanny.pdf. Acesso em: 12 jul. 2019.

GABRIEL, Marcos Faccioli. Mário Pedrosa e a arquitetura brasileira: autonomia e síntese das artes. 2017. Tese (Doutorado em História e Fundamentos da Arquitetura e do Urbanismo) - Faculdade de Arquitetura e Urbanismo da USP, São Paulo, 2017.

GIEDION, Siegfried; SERT, José Luis.; LÉGER, Fernand. Nine points on monumentality. In: OACKMAN, Joan (org.). Architecture culture 1943-1968. New York: Columbia Books of Architecture/Rizzoli, 1993. p. 29-30.

HÜBSCH, Heinrich. In what style should we build? In: HERRMANN, Wolfgang. (org.). In what style should we build? The german debate on architectural style. Santa Monica, CA: The Getty Center Publications Programs, 1992. p. 1-60

KAMITA, João Masao. Vilanova Artigas. São Paulo: Cosac \& Naify Edições, 2000. MOTTA, F. Introduzione al Brasile. Zodiac, [Itália], n. 6, p. 61-67, 1960.

PEDROSA, Mário. A Arquitetura Moderna no Brasil [1953]. In: AMARAL, Aracy A. (org.). Dos murais de Portinari aos espaços de Brasília. São Paulo: Perspectiva, 1981a.p. 255-264.

PEDROSA, Mário. A bienal de cá para lá. In: MAMMÌ, Lorenzo (org.). Mário Pedrosa: arte ensaios. São Paulo: Cosac \& Naify, 2015b. p. 467-516.

PEDROSA, Mário. A cidade nova, síntese das artes. In: AMARAL, Aracy A. (org.). Dos murais de Portinari aos espaços de Brasília. São Paulo: Perspectiva, 1981c. p. 355-363.

PEDROSA, Mário. A máquina, Calder, Léger e outros. In: PEDROSA, Mário. Arte necessidade vital. Rio de Janeiro: Livraria Editora da Casa do Estudante do Brasil, 1949. p. 129-142.

PEDROSA, Mário. A propósito do “estilo século XX” [1957]. In: WISNIK, G. (org.). Mário Pedrosa: arquitetura ensaios. São Paulo: Cosac \& Naify, 2015a. p. 41-42.

PEDROSA, Mário. Arquitetura e crítica de arte I [1957]. In: AMARAL, Aracy A. (org.). Dos murais de Portinari aos espaços de Brasília. São Paulo: Perspectiva, 1981b. p.269-271.

PEDROSA, Mário. Brasília, a cidade nova. In: AMARAL, Aracy A. (org.). Dos murais de Portinari aos espaços de Brasília. São Paulo: Perspectiva, 1981e. p.345-353. 
PEDROSA, Mário. CONGRESSO NACIONAL DE CRÍTICOS DE ARTE, 2., 1961, São

Paulo. Anais [...]. São Paulo, 1961.

PEDROSA, Mário. Fundamentos da arte abstrata [1953]. In: PEDROSA, Mário. Dimensões da arte. Rio de Janeiro: Ministério da Educação e Cultura, 1964. p. 207-215.

PEDROSA, Mário. Reflexões em torno da nova capital. In: AMARAL, Aracy A. (org.). Dos murais de Portinari aos espaços de Brasília. São Paulo: Perspectiva, 1981d. p.303-316.

PRÊMIOS UIA 1984 para Lúcio Costa e Vilanova Artigas. Projeto, São Paulo, n. 70, p. 51, dez. 1984.

SCHOPENHAUER, Arthur. The world as will and representation. New York: Dover, 1969. $2 \mathrm{v}$.

VALÉRY, Paul. Eupalinos ou o Arquiteto. São Paulo: Editora 34, 1996.

VIDLER, Anthony. The architectural uncanny: essay in the modern unhomely. Cambridge, Massachusetts: The MIT Press, 1996.

VITRÚVIO. Da arquitetura. São Paulo: Hucitec/Fupam, 1999.

\section{Notas}

${ }^{1}$ Professor de teoria e história no curso de Arquitetura e Urbanismo da Faculdade de Ciências e Tecnologia da UNESP em Presidente Prudente. Doutor pela Faculdade de Arquitetura e Urbanismo da Universidade de São Paulo com a tese: "Mário Pedrosa e a arquitetura brasileira: autonomia e síntese das artes”. ORCID http://orcid.org/00000002-0802-0896.Email:m.gbr@uol.com.br.

${ }^{2}$ Este congresso de críticos de arte foi promovido pela Associação Internacional de Críticos de Arte, AICA, a qual foi fundada em 1948 como parte da UNESCO. Mário Pedrosa ocupou a presidência da entidade nos primeiros anos, o que fez dele uma referência internacional sobre o campo cultural no Brasil, sobre as bienais e as realizações da arquitetura moderna no país, bem como uma personalidade aglutinadora no movimento latino-americano pela arte abstrata construtiva. Pedrosa, nesta posição, organizou o congresso extraordinário itinerante da entidade no Brasil para apresentar Brasília à crítica internacional, o que constituiu uma ação política em cooperação, ainda que limitada, com o governo de Juscelino Kubitschek, com o qual Pedrosa tinha outros tantos atritos (CONGRESSO INTERNACIONAL EXTRAORDINÁRIO DE CRÍTICOS DE ARTE, 1959).

${ }^{3}$ Os escritos não publicados de Artigas devem ser lidos com algumas ressalvas. Eram notas pessoais de um arquiteto praticante que procurava orientar-se num mundo de significados elaborados por literaturas de diversos tipos. Enquanto escritos propriamente, estão abaixo do padrão profissional, prestando-se, porém, a uma observação de suas 
posições.

${ }^{4}$ Em outubro de 1984, o Júri Internacional da UIA (Paris) fez a premiação trienal, concedendo a Artigas o prêmio August Perret para Tecnologia Aplicada à Arquitetura por ser considerado pioneiro na América Latina na tecnologia dos pontos de apoio, uma tecnologia originada da alta engenharia civil. Veja-se: PRÊMIOS UIA (1984).

${ }^{5}$ Esse tipo de associação entre a pedra na horizontal e o corpo morto é explorado também na escultura moderna, como na instalação "O fim do Século XX" de Joseph Beuys.

${ }^{6}$ Este trabalho procede de uma atualização do projeto de pesquisa em mestrado que apresentamos à EESC USP em 1998 e concluímos em 2003 sob orientação da Profa. Dra. Cibele S. Rizek.

${ }^{7}$ Alan Colquhoun (2004, p. 75) atribui este argumento a Viollet-Le-Duc: “[...] para Viollet-le-Duc, a história da arquitetura é um desenvolvimento contínuo que exclui a possibilidade de repetição das formas 'perfeitas' decorrentes da Antiguidade. A morfologia da arquitetura não mais é determinada por uma taxonomia de formas externas e históricas, mas sim por um sistema de funções subjacentes. 'Aquilo que geralmente é considerado como o tema da verdadeira arte, a saber, a simetria, a forma aparente, é uma consideração totalmente secundária'. 